\title{
Nitrogen and phosphorus in cascade multi-system tropical reservoirs: water and sediment
}

\author{
Marcelo Pompêe ${ }^{1 *}$, Viviane Moschini-Carlos ${ }^{2}$, Julio Cesar López-Doval ${ }^{1}$, Natália Abdalla-Martins ${ }^{1}$, \\ Sheila Cardoso-Silva ${ }^{2}$, Rogério Herlon Furtado Freire ${ }^{3}$, Frederico Guilherme de Souza Beghelli², \\ Ana Lúcia Brandimarte ${ }^{1}$, André Henrique Rosa ${ }^{2}$, Pilar López ${ }^{4}$
}

\author{
${ }^{1}$ São Paulo University (USP), Bioscience Institute, Department of Ecology, Rua do Matão 321 / Travessa 14, Cidade Universitária, CEP \\ 05508-090, São Paulo, Brazil, e-mail: mpompeo@ib.usp.br ( ${ }^{*}$ corresponding author) \\ ${ }^{2}$ São Paulo State University (UNESP), Department of Environmental Engineering, Avda. 3 de Março 511, Alto da Boa Vista, CEP 18087- \\ 180, Sorocaba, Brazil \\ ${ }^{3}$ São Paulo Virtual University (UNIVESP), Brazil \\ ${ }^{4}$ Barcelona University, Department of Ecology, Avda. Diagonal 645, 08034 Barcelona, Spain
}

\begin{abstract}
The aim of this research was to analyze the horizontal spatial heterogeneity of both water and superficial sediment quality among and within the reservoirs of the Cantareira System (CS), focusing on concentrations of N and P, attributed to the dumping of raw domestic sewage into water bodies, which is the main cause of water pollution in São Paulo State (Brazil). The CS is a multi-system complex composed of five interconnected reservoirs, with water transported by gravity through $48 \mathrm{~km}$ of tunnels and channels. From the last reservoir of the CS, with an output of $33 \mathrm{~m}^{3} \mathrm{~s}^{-1}$, the water is conducted to a water treatment plant, producing half of the water consumed by 19 million people inhabiting São Paulo city. The upstream reservoirs are more eutrophic than the downstream ones. Data also suggest that the low phytoplankton biomass (ranging from 0.9 to $14.4 \mu \mathrm{g} \mathrm{dm}^{-3}$ ) is regulated by the low nutrient availability, mainly of phosphorus (TP ranging from below the detection limit, $<9.0 \mu \mathrm{g} \mathrm{dm}^{-3}$, to $47.3 \mu \mathrm{g} \mathrm{dm}^{-3}$ ). For water, the DIN/TP ratios values range from 19 to 380 . The upstream reservoirs function as nutrient accumulators and the sediment is the main compartment in which $\mathrm{P}$ and $\mathrm{N}$ are stored. Although the reservoirs are located in different river basins and are not in sequence along the same river, the results suggest a marked gradient between the reservoirs, with features similar to those of cascade reservoirs. The large volumes flowing through the canals and tunnels could explain the observed pattern. The CS reservoirs can therefore be considered multi-system reservoirs in cascade, constituting a particular case of multi-system reservoirs.
\end{abstract}

Key words: cascade reservoir, sediment, water quality, nitrogen, phosphorus

\section{Introduction}

Water is an essential resource for ecosystems and economic development. Increases in water demand, as well as in water pollution in some countries, have led to the construction of reservoirs to ensure water quality and availability, especially in highly urbanized regions (Lehner et al. 2011; Liu et al. 2016). In South America, economic development is resulting in increased requirements for water storage and energy production. In order to meet these demands, a large number of reservoirs have been constructed in the region during the $20^{\text {th }}$ and $21^{\text {st }}$ centuries, providing recreational services and playing an important role in economic development (Tundisi et al. 1998).
Despite their benefits, reservoirs alter both water flows and the surrounding terrestrial and aquatic ecosystems, requiring well-founded scientific and engineering methodologies when constructing them (Tundisi and Matsumura-Tundisi 2008, 2010). Therefore, it is important to understand the dynamics, structure, and functioning of reservoirs in order to model new projects and to manage reservoirs currently in operation. This is especially important in the case of interconnected reservoirs; such as cascade or multi-system reservoirs (Barbosa et al. 1999).

The concept of cascade reservoirs refers to a set of reservoirs constructed in sequence along the same river (Straškraba et al. 1993; Barbosa et al. 1999; Tundisi and Matsumura-Tundisi 2008; Straškraba and Tundisi 
2013). Multiple reservoir systems are those that comprise a set of reservoirs located in different river systems, in different watersheds (Straškraba et al. 1993; Straškraba and Tundisi 2013). In order to understand the processes in one reservoir of a cascade or multiple reservoir system, it is important to study all the reservoirs in the system, since effects on water quality and quantity in the upstream reservoirs can significantly affect the physical, chemical, and biological aspects of the downstream reservoirs.

The largest urban and industrial complex in South America is the Metropolitan Region of São Paulo (MRSP), located in São Paulo State (Brazil) (Braga et al. 2006). The MRSP has experienced dramatic and unplanned growth in the last 50 years, and now includes the city of São Paulo and a further 39 municipalities, with a total population of around 21,000,000 inhabitants and an area of $8,000 \mathrm{~km}^{2}$. The main land use in the MRSP is for urban and industrial purposes (Ducrot et al. 2005; Braga et al. 2006; SEADE 2015), and the reservoirs in this region are vital for water supply and energy production (Tundisi et al. 1998; Ducrot et al. 2005). The MRSP is supplied by different reservoirs, among which are the reservoirs of the Cantareira System (Pereira 2013), the object of study in this research.

Despite their importance in providing multiple benefits to the population, the reservoirs in this region are often severely impacted by human activities. The most common effect is eutrophication, which is a consequence of high nitrogen and phosphorus concentrations and can cause additional contamination. For example, eutrophication can lead to the growth of harmful algae, whose control requires the application of hydrogen peroxide or copper sulfate, which can result in contamination of the sediment by copper (Caleffi 2000; CETESB 2008; Mariani and Pompêo 2008; Pompêo et al. 2013). Causal relationships have been suggested between high levels of nutrients and the presence of other pollutants in superficial waters and sediments. These include organic compounds and emerging contaminants (Sodré et al. 2010; Bergamasco et al. 2011; Santos et al. 2012; López-Doval et al. 2015), as well as pharmaceutical products (Almeida and Weber 2005; Huerta et al. 2013). All these substances can potentially be transferred to the water used for human consumption (Jones et al. 2005; Sodré et al. 2010; Barbosa et al. 2015). Although eutrophication is not a recent problem (Margalef et al. 1976; Vallentyne 1978; UNEP-IETC 2001), it is still persistent in Brazil and elsewhere worldwide (Qin et al. 2013; Azevedo et al. 2015; Vidović et al. 2015), requiring constant attention by researchers and environmental managers.

Therefore, the aim of this research was to analyze the horizontal spatial heterogeneity of water and superficial sediment quality among and within the reservoirs of the Cantareira System, focusing on the concentrations of $\mathrm{N}$ and $\mathrm{P}$. Excess of these elements is mainly attributed to the dumping of raw domestic sewage in the water bodies, which is the main cause of water pollution in São Paulo State (CETESB 2013). The results will be used to investigate whether the integrated operation of these reservoirs may be based on the Cascade Reservoirs Continuum Concept (CRCC) (Barbosa et al. 1999). According to these authors, the presence of cascaded reservoirs causes significant changes in the original continuum of a river, while the physical, chemical and biological characteristics and the functioning of the downstream reservoirs also cause physical, chemical and biological changes in water quality. The upstream reservoirs will also be verified in this work. Thus, based on the CRCC, we expect the upstream reservoirs to be more eutrophic than the downstream reservoirs.

\section{Materials and Methods}

\section{Study area description}

With an output of $33 \mathrm{~m}^{3} \mathrm{~s}^{-1}$, the Cantareira System (CS) produces half the water consumed by the population of the MRSP (Whately and Cunha 2007).

The first stage of operation this System was completed in 1974, and today the CS consists of five interconnected reservoirs (Jaguari - JG, Jacarei - JC, Cachoeira - CA, Atibainha - AT, and Paiva Castro - PC), with transfer of water by gravity through $48 \mathrm{~km}$ of tunnels and channels (Fig. 1). From the last reservoir, the Paiva Castro, the water is conducted for treatment and is finally distributed to the MRSP (Gomes 2004; Carvalho and Thomas 2007; Whately and Cunha 2007).

In the CS reservoirs, only small volumes of water are discharged through the dams in order to maintain the outflows of the rivers. The main interconnection, in terms of the volume transferred between the reservoirs, occurs through artificially constructed channels and tunnels (dashed lines in Fig. 1), allowing the transfer of water by gravity from the upstream to the downstream reservoirs (Gomes 2004; Carvalho and Thomas 2007; Whately and Cunha 2007). Hence, the CS reservoirs do not fit the classical definition of cascade reservoirs (Straškraba et al. 1993; Barbosa et al. 1999), but approach the definition of multi-system reservoirs (Straškraba et al. 1993; Straškraba and Tundisi 2013).

In multiple reservoir systems, hydrochemical differences in the watershed areas can create specific problems concerning limnology and water quality in the different reservoirs that compose the system (Straškraba and Tundisi 2013), since different geological formations can lead to specific chemical characteristics of each individual reservoir. Furthermore, the use and 

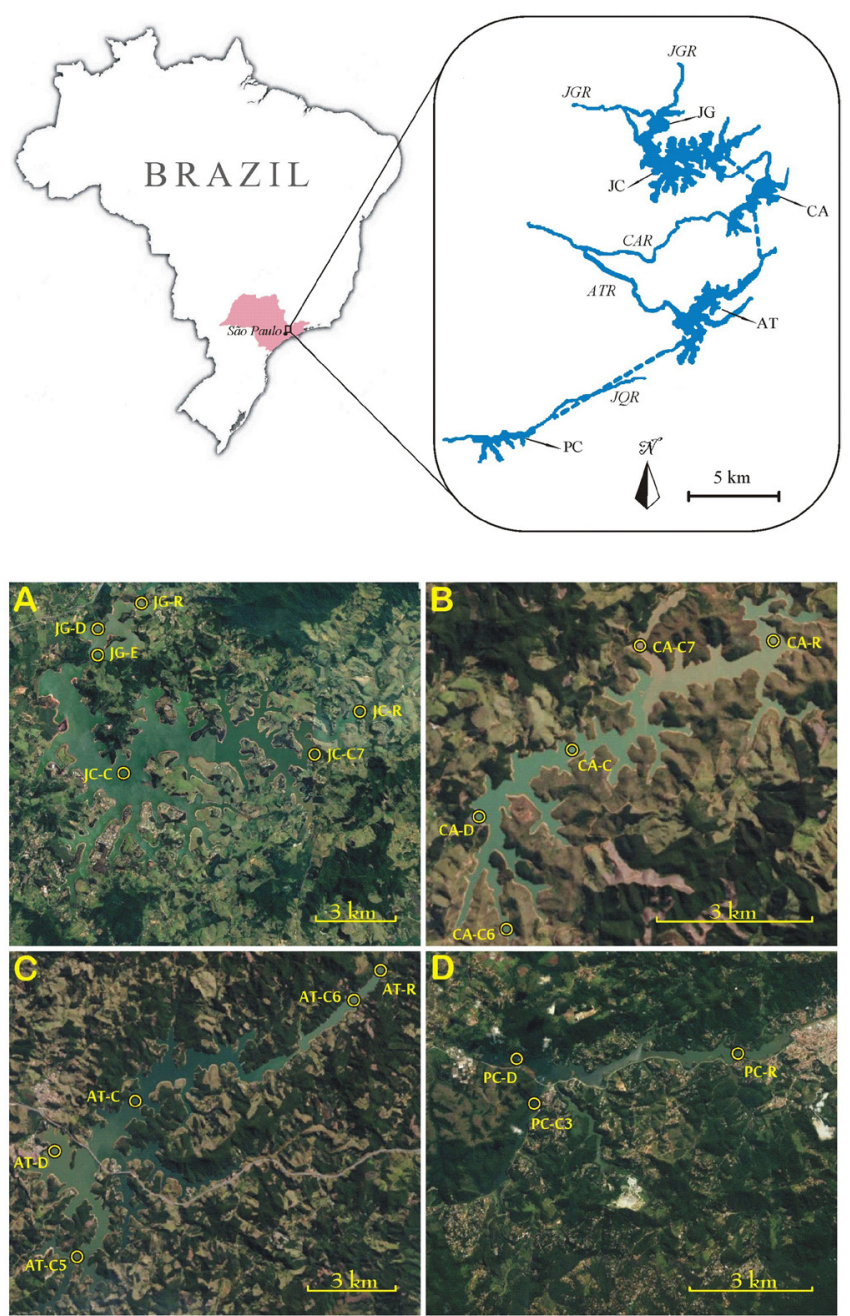

Fig. 1. Location of the reservoirs that compose the Cantareira Water Supply System (water flow channels between the reservoirs are marked with dashed lines) and sampling stations location in the Jaguari and Jacarei reservoirs (A), the Cachoeira Reservoir (B), the Atibainha Reservoir (C), and the Paiva Castro Reservoir (D)

occupation of land in each watershed area are also important, because inputs from a variety of anthropogenic

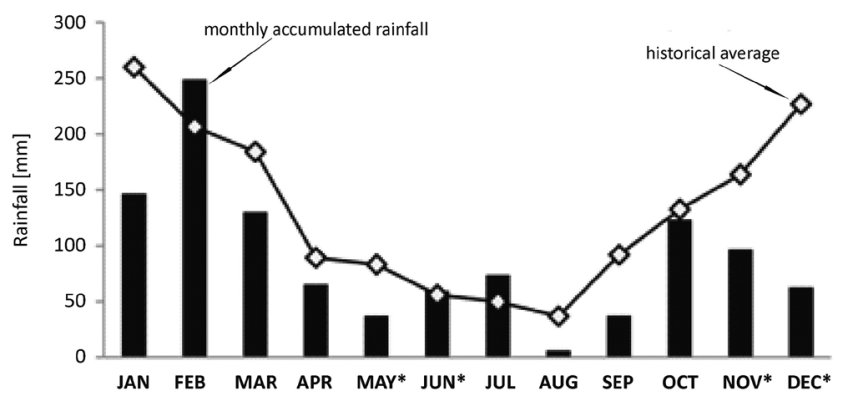

Fig. 2. Monthly-accumulated rainfall of the Cantareira System in 2013 (bars), and historical average of rainfall in the last 10 years (line) Asterisk $\left(^{*}\right)$ means sampling months

Data from: http://www2.sabesp.com.br/mananciais/DivulgacaoSiteSabesp. aspx

activities modify the water and sediment quality of the different reservoirs.

The watersheds of the CS have had more than half of their areas altered by human activities (Whately and Cunha 2007), characterized by high percentages of urban and other anthropic land uses. Natural vegetation cover is usually low, and inadequate sanitation services include low rates of collection and treatment of wastewater from the municipalities of the CS (Whately and Cunha 2007). In the MRSP, only $45 \%$ of the population has access to sewage treatment facilities (Pompêo and Moschini-Carlos 2012), while the untreated fraction results in large pollutant inputs to the receiving water bodies. All of these factors lead to a worrying scenario, as already observed, for instance, in the basins of the Billings and Guarapiranga reservoirs, also located in the MRSP. For decades, both drainage basins of those reservoirs have experienced substantial impacts that are reflected in the water and sediment quality, particularly due to eutrophication (Mariani and Pompêo 2008; Moschini-Carlos et al. 2009, 2010; Pompêo et al. 2013; Cardoso-Silva et al. 2014; Nishimura et al. 2014; Pompêo, Kawamura et al. 2015).

Table 1 presents the hydrological information and characteristics of the CS reservoirs, according to ANA-

Table 1. Characteristics and hydrological information of the Cantareira System reservoirs

\begin{tabular}{lccccccc}
\hline \multicolumn{1}{c}{ Characteristics } & Unit & Jaguari $^{* *}$ & Jacarei $^{* *}$ & Jaguari / Jacarei & Cachoeira & Atibainha & Paiva Castro \\
\hline Average rainfall & {$[\mathrm{mm}]$} & NA & NA & 1592 & 1763 & 1642 & 1593 \\
\hline Drainage area & {$\left[\mathrm{km}^{2}\right]$} & NA & NA & $1027 / 203$ & 392 & 312 \\
\hline Live/useful storage & {$\left[\mathrm{hm}^{3}\right]$} & 96 & 713 & 808.12 & 69.75 & 95.26 & 7.61 \\
\hline Dead storage & {$\left[\mathrm{hm}^{3}\right]$} & 39 & 204 & 239.43 & 46.81 & 194.93 & 25.33 \\
\hline Maximum flooded area & {$\left[\mathrm{km}^{2}\right]$} & NA & NA & 49.91 & 8.6 & 21.8 & 4.6 \\
\hline Average flow & {$\left[\mathrm{m}^{3} \mathrm{~s}^{-1}\right]$} & NA & NA & 25.2 & 8.5 & 6.0 \\
\hline Quota & {$[\mathrm{m}]$} & 844.0 & 844.0 & 844.0 & 821.88 & 786.72 & 745.61 \\
\hline Residence time & $\left.{ }^{*}\right)$ & {$[$ days] } & NA & NA & 368.5 & 40.1 & 105.8 \\
\hline
\end{tabular}

Data series for the period from 1 January 2004 to 31 December 2012, according to National Water Agency (ANA 2013)

* Based on the average of the daily flows downstream of dams and through tunnels, using the input volumes in the corresponding upstream reservoir and the daily volumes of each reservoir, ${ }^{* *}$ Personal communication by Luiz Almada de Alencar Barros (10 June 2014), NA - not available 
DAEE (2013). From the point of view of the CS managers, Jaguari and Jacareí are always treated as a single reservoir. The Jaguari/Jacareí reservoirs have the longest residence time (RT), while the Paiva Castro has the shortest. Based on historical averages for the region, the months of May and June are considered a period of low rainfall, comprising a dry season, while November and December typically constitute a rainy period (Fig. 2). However, in November and December of 2013, the rainfall was far below historical averages.

\section{Sampling and analytical methods}

Water and sediment were sampled at 19 sites in May and June (first sampling period) and in November and
December (second sampling period) of 2013 (Fig. 1, Table 2). The selection of sampling sites took into account the three theoretical zones in reservoirs (riverine, transitional, and lacustrine) (Kimmel et al. 1990) and the zones of inlet and outlet of water through the respective connecting channels (Fig. 1, Table 2).

At each site, three samples of the superficial sediment ( $0-4 \mathrm{~cm}$ depth) were collected using a Lenz type grab sampler $\left(225 \mathrm{~cm}^{2}\right)$. An aliquot of each sample was removed for the determination of nitrogen, determined as total Kjeldahl nitrogen (TKN) (APHA 2005), total phosphorus (Andersen 1976), and organic matter (Meguro 2000 - furnace muffle, $550^{\circ} \mathrm{C}$, for $1-2$ hours). The aliquots were stored in plastic bottles that

Table 2. Sampling site general characteristics, sample collection dates, and abbreviations used in the body text. For each site, the first and second coordinates correspond to the first and second sampling periods, respectively

\begin{tabular}{|c|c|c|c|c|c|c|c|}
\hline \multirow{2}{*}{ Reservoir } & \multirow{2}{*}{ Date } & \multirow{2}{*}{ Symbol } & \multicolumn{2}{|c|}{ Depth [m] } & \multicolumn{2}{|c|}{ Coordinates UTM-23K } & \multirow{2}{*}{ Description } \\
\hline & & & Maximum & Sampling & $\mathrm{X}$ & $\mathrm{Y}$ & \\
\hline \multirow{6}{*}{$\begin{array}{l}\text { Jaguari } \\
\text { (JG) }\end{array}$} & \multirow{6}{*}{$\begin{array}{l}21 \text { Jun } 2013 \\
11 \text { Dec } 2013\end{array}$} & JG-R & 14.4 & 5.0 & 0355748 & 7465315 & Entrance of Jaguari river \\
\hline & & & 14.0 & 5.0 & 0355751 & 7465297 & \\
\hline & & JG-D & 41.0 & 5.0 & 0354115 & 7463800 & Dam \\
\hline & & & 31.0 & 5.0 & 0354100 & 7463896 & \\
\hline & & JG-E & 32.0 & 5.0 & 0354190 & 7462807 & Water outflow for Jacareí reservoir \\
\hline & & & 29.7 & 5.0 & 0354060 & 7462875 & \\
\hline \multirow{6}{*}{$\begin{array}{l}\text { Jacareí } \\
\text { (JC) }\end{array}$} & \multirow{6}{*}{$\begin{array}{l}21 \text { Jun } 2013 \\
11 \text { Dec } 2013\end{array}$} & $\mathrm{JC}-\mathrm{C}$ & 33.0 & 5.0 & 0355758 & 7458048 & Central region \\
\hline & & & 31.0 & 5.0 & 0353448 & 7459932 & \\
\hline & & JC-R & 7.2 & 3.0 & 0365259 & 7460887 & Entrance of Jacareí river \\
\hline & & & 3.5 & 2.0 & 0364386 & 7460017 & \\
\hline & & $\mathrm{JC}-\mathrm{C} 7$ & 15.4 & 5.0 & 0363398 & 7459240 & Water outflow for Cachoeira reservoir, through \\
\hline & & & 14.0 & 5.0 & 0363446 & 7459097 & channel 7 \\
\hline \multirow{10}{*}{$\begin{array}{l}\text { Cachoeira } \\
\text { (CA) }\end{array}$} & \multirow{10}{*}{$\begin{array}{l}13 \text { Jun } 2013 \\
28 \text { Nov } 2013\end{array}$} & CA-R & 6.0 & 3.0 & 0371005 & 7454767 & Entrance of Cachoeira river \\
\hline & & & 7.9 & 3.0 & 0370729 & 7454793 & \\
\hline & & CA-C7 & 10.6 & 5.0 & 0367864 & 7454158 & Water inlet from Jacarei reservoir \\
\hline & & & 8.8 & 3.0 & 0368022 & 7454356 & \\
\hline & & CA-C & 22.5 & 5.0 & 0366627 & 7451824 & Central region \\
\hline & & & 12.6 & 5.0 & 0366860 & 7451874 & \\
\hline & & CA-D & 17.5 & 5.0 & 0365003 & 7450572 & Dam \\
\hline & & & 22.3 & 5.0 & 0365216 & 7450760 & \\
\hline & & CA-C6 & 11.2 & 5.0 & 0365593 & 7448362 & Water outflow for Atibainha reservoir, through \\
\hline & & & 11.6 & 5.0 & 0365600 & 7448342 & channel 6 \\
\hline \multirow{10}{*}{$\begin{array}{l}\text { Atibainha } \\
\text { (AT) }\end{array}$} & \multirow{10}{*}{$\begin{array}{l}26 \text { Jun } 2013 \\
4 \text { Dec } 2013\end{array}$} & AT-R & 3.0 & 2.0 & 0368908 & 7443243 & Entrance of Atibainha river \\
\hline & & & 4.8 & 2.0 & 0368939 & 7443336 & \\
\hline & & AT-C6 & 5.5 & 3.0 & 0368035 & 7442070 & Water inlet from Cachoeira reservoir \\
\hline & & & 5.0 & 2.0 & 0368162 & 7442213 & \\
\hline & & AT-C & 22.0 & 5.0 & 0360222 & 7437283 & Central region \\
\hline & & & 19.5 & 5.0 & 0360818 & 7438236 & \\
\hline & & AT-D & 22.0 & 5.0 & 0357951 & 7436093 & Dam \\
\hline & & & 12.9 & 5.0 & 0357690 & 7436419 & \\
\hline & & AT-C5 & 16.6 & 5.0 & 0358829 & 7432274 & Water outflow for Paiva Castro reservoir, through \\
\hline & & & 19.0 & 5.0 & 0359580 & 7432904 & channel 5 \\
\hline \multirow{6}{*}{$\begin{array}{l}\text { Paiva Castro } \\
\text { (PC) }\end{array}$} & \multirow{6}{*}{$\begin{array}{l}29 \text { May } 2013 \\
21 \text { Nov } 2013\end{array}$} & PC-R & 5.5 & 3.0 & 0335438 & 7419400 & Juqueri river and water channel 5 entrance \\
\hline & & & 5.0 & 2.0 & 0335357 & 7419369 & \\
\hline & & PC-D & 14.0 & 5.0 & 0329039 & 7418788 & Dam \\
\hline & & & 14.1 & 5.0 & 0329082 & 7418781 & \\
\hline & & PC-C3 & 10.0 & 5.0 & 0329794 & 7416808 & Arm that carries water to Santa Ines pumping \\
\hline & & & 8.6 & 3.0 & 0329752 & 7416746 & station \\
\hline
\end{tabular}

Coordinates measured with UTM WGS Datum 84 
had been previously washed with hydrochloric acid $(10 \%, \mathrm{v} / \mathrm{v})$.

Integrated surface water samples (INAG IP 2009) were collected at each sampling site using a one-inch diameter garden hose (Navarro et al. 2006; Becker et al. 2010), with modifications. Garden hoses 5, 3, and $2 \mathrm{~m}$ in length were used when the depths of the sampling sites were greater than $10 \mathrm{~m}$, between 10 and $5 \mathrm{~m}$, and less than $5 \mathrm{~m}$, respectively (Table 2 ). The hose was repeatedly launched until a 5 liter volume of water had been collected, which was stored in a plastic bottle and kept inside a cool bag until transported to the laboratory. The water samples were filtered (AP40, Millipore) within 24 hours after sampling, prior to the determination of chlorophyll- $a$ and phaeopigments (Lorenzen 1967), suspended materials (Wetzel and Likens 1991), nitrate (Method 8192 Hach), nitrite (Mackereth et al. 1978), and ammonium (Koroleff 1976). The total phosphorus concentration was determined using unfiltered samples (Valderrama 1981). Measurements of temperature, dissolved oxygen, percentage of dissolved oxygen saturation, $\mathrm{pH}$, and electrical conductivity were taken throughout the vertical profiles at all the sampling stations, using a multiparametric probe (U52, Horiba). The maximum depth (Echotest II, Plastimo) and the water column transparency ( $30 \mathrm{~cm}$ Secchi disk) were also determined in situ. The euphotic zone was estimated according to Cole (1979), by multiplying the Secchi disk values by 2.7. The trophic state index (TSI) was calculated based on the arithmetic mean of the TSI obtained from the concentration of total phosphorus in the water and the TSI obtained from the concentration of chlorophyll- $a$, as described by Carlson (1977) and modified by Lamparelli (2004), adapted to Brazilian reservoirs, using the values for the integrated water column.

The data were analyzed by means of cluster analysis (CA) and principal component analysis (PCA) in order to identify the patterns of variation of the environmental data between the reservoirs and sampling points. The environmental variables were normalized by the ranging method (the ratio between the gross value less the minimum value and the maximum value less the minimum value of each variable) and were analyzed with PAST 2.17c software (Hammer et al. 2001). PCA was carried out considering the variance between the groups (reservoirs) that were defined a priori in the analysis. The CA and PCA procedures were performed using the values for DIN (dissolved inorganic nitrogen: nitrate + nitrite + ammonium), transparency, suspended solids, organic and inorganic fractions (sediment and water), total Kjeldahl nitrogen and total phosphorus in the sediment, and TSI.

Concentrations of total phosphorus and ammonium in water below the detection limit of the methods $\left(9.0 \mu \mathrm{g} \mathrm{dm}^{-3}\right.$ for total phosphorus and $18.0 \mu \mathrm{g} \mathrm{dm}^{-3}$ for ammonium) were changed to half of these values for use in the graphics and statistical analyses, as suggested by Newman et al. (1989), Lewis et al. (2007), and DDE (2012). We adopted this procedure in order to avoid unnecessary loss of information.

\section{Results and Discussion}

Table 3 presents the range of variation of the variables analyzed in the sediment and water. Probe data refer to the weighted average for the same depth of the integrated samples. For the water, the electrical conductivity (EC) and trophic state index (TSI) presented the lowest range of variation, while the dissolved nutrient contents presented the highest variation. The inorganic fraction of the sediment had the lowest range of variation (lower CV). When comparing the same variable for water and sediment (total phosphorus or total nitrogen), the coefficient of variation was higher for the water (44-100\%) than the sediment (20-25\%), probably due to the greater dynamism of the water column, compared to the sediment.

In Figures 3 and 4, the data presentation is organized following the water path through the system of reservoirs, from the Jaguari river portion (JG-R) to the water outlet channel to the Santa Ines pumping station in the Paiva Castro reservoir (PC-C3), passing through the Jacareí, Cachoeira, and Atibainha reservoirs. Some of the variables showed a trend towards higher values in the first reservoirs of the CS (Jaguari and Jacareí). This was particularly evident for DIN, nitrite, nitrate, ammonium, total phosphorus (TP), chlorophyll- $a$, and suspended solids (SS), especially in the second sampling period (November/December 2013). The Secchi disk (SD) data showed a trend towards higher values in the downstream reservoirs, especially for the second sampling period. The TSI presented a trend towards higher values in the upstream reservoirs, with the Jaguari being most eutrophic (Fig. 3).

The sediment showed no clear pattern through the reservoirs in terms of the total Kjeldahl nitrogen (TKN) concentration (Fig. 5). However, a trend towards lower concentrations of TP through the reservoirs was observed, with the lowest values for the Paiva Castro reservoir.

The data for the water column revealed statistically significant and positive linear regressions between chlorophyll- $a$ and the variables DIN, nitrite, nitrate, ammonium, TP, and SS. Chlorophyll- $a$ was negatively related to SD (Fig. 6). There were positive regressions between DIN and TP, and negative ones between SS and SD.

The data suggested the separation of the reservoirs into two major groups (Fig. 6). The first group, consisting 
Table 3. Variables analyzed in the water and sediment of the Cantareira System reservoirs during two periods (May/June and November/ December 2013). Explanations: STD - standard deviation; CV - coefficient of variation [\%]; DIN - dissolved inorganic nitrogen (nitrite + nitrate + ammonium)

\begin{tabular}{|c|c|c|c|c|c|c|c|}
\hline & Variable & Unit & Minimum & Maximum & Average & STD & $\mathrm{CV}$ \\
\hline \multirow{21}{*}{$\frac{\frac{1}{\omega}}{\frac{\pi}{3}}$} & Maximum depth & {$[\mathrm{m}]$} & 3.0 & 41.0 & 15.2 & 9.7 & 64.1 \\
\hline & Temperature & {$\left[{ }^{\circ} \mathrm{C}\right]$} & 18.5 & 25.9 & 21.8 & 2.7 & 12.2 \\
\hline & Electrical conductivity (EC) & {$\left[\mu \mathrm{S} \mathrm{cm}^{-1}\right]$} & 27.5 & 39.6 & 33.0 & 2.1 & 6.3 \\
\hline & $\mathrm{pH}$ & & 5.7 & 8.5 & 6.8 & 0.7 & 10.4 \\
\hline & Dissolved oxygen (DO) & {$\left[\mathrm{mg} \mathrm{dm}^{-3}\right]$} & 5.8 & 12.2 & 8.2 & 1.6 & 19.5 \\
\hline & DO saturation & [\%] & 70.3 & 147.4 & 103.2 & 20.3 & 19.7 \\
\hline & Nitrite & {$\left[\mu \mathrm{g} \mathrm{dm}^{-3}\right]$} & 0.4 & 27.6 & 4.9 & 7.0 & 143.2 \\
\hline & Nitrate & {$\left[\mu \mathrm{g} \mathrm{dm}^{-3}\right]$} & 164.9 & 713.8 & 329.7 & 129.7 & 39.3 \\
\hline & Ammonium & {$\left[\mu \mathrm{g} \mathrm{dm}^{-3}\right]$} & $9.0^{*}$ & 177.9 & 27.5 & 32.8 & 119.4 \\
\hline & DIN & {$\left[\mu \mathrm{g} \mathrm{dm}^{-3}\right]$} & 179.4 & 900.1 & 362.1 & 159.7 & 44.1 \\
\hline & Total phosphorus (TPw) & {$\left[\mu \mathrm{g} \mathrm{dm}^{-3}\right]$} & $4.5^{*}$ & 47.3 & 8.5 & 9.4 & 109.9 \\
\hline & Chlorophyll-a & {$\left[\mu \mathrm{g} \mathrm{dm}^{-3}\right]$} & 0.9 & 14.1 & 3.5 & 3.7 & 108.0 \\
\hline & Phaeophytin & {$\left[\mu \mathrm{g} \mathrm{dm}^{-3}\right]$} & 0.6 & 8.9 & 3.2 & 1.9 & 60.9 \\
\hline & Secchi disk (SD) & [m] & 0.5 & 4.3 & 2.3 & 0.9 & 41.7 \\
\hline & Photic zone $\left({ }^{* *}\right)$ & [m] & 1.35 & 11.6 & 6.2 & 2.6 & 41.7 \\
\hline & Suspended solids (SS) & {$\left[\mathrm{mg} \mathrm{dm}^{-3}\right]$} & 1.1 & 27.4 & 4.1 & 4.9 & 118.5 \\
\hline & SSO - organic fraction & {$[\%]$} & 19.3 & 100.0 & 60.0 & 21.8 & 36.3 \\
\hline & SSI - inorganic fraction & [\%] & 0.0 & 80.7 & 40.0 & 21.8 & 54.4 \\
\hline & Trophic state index (TSI) & & 51 & 64 & 54 & 3.7 & 6.8 \\
\hline & Trophic classification & & oligotrophy & supereutrophy & mesotrophy & & \\
\hline & DIN/TPw & & 19 & 380 & 138 & 68 & 49.6 \\
\hline \multirow{5}{*}{ 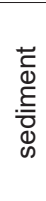 } & Total Kjeldahl nitrogen (TKN) & [g TKN kg-1DW] & 1.2 & 4.1 & 2.8 & 0.7 & 25.0 \\
\hline & Total phosphorus (TPs) & [mg P kg-1DW] & 217.5 & 548.1 & 371.0 & 81.8 & 22.1 \\
\hline & Organic fraction & [\%] & 7.1 & 19.4 & 15.0 & 3.0 & 19.8 \\
\hline & Inorganic fraction & [\%] & 80.6 & 92.9 & 85.0 & 3.0 & 3.5 \\
\hline & TKN/TPs & & 7 & 29 & 17 & 5 & 28.1 \\
\hline
\end{tabular}

* Values corresponding to half the detection limit used in the graphics and the statistical analyses (detection limits: $9.0 \mu \mathrm{g} \mathrm{dm}{ }^{-3}$ for $\mathrm{TPw}_{\text {and }} 18.0 \mu \mathrm{g} \mathrm{dm}{ }^{-3}$ for ammonium); ${ }^{* *}$ Photic zone: $2.7 \times$ SD (Cole 1979)

of the Jaguari and Jacareí reservoirs, was characterized by high levels of DIN (nitrite + nitrate + ammonium) and TP, which caused higher concentrations of chlorophyll- $a$ and SS, resulting in lower SD and higher TSI values. The other major group consisted of the Cachoeira, Atibainha, and Paiva Castro reservoirs, with lower levels of nutrients (nitrogen and TP) and SS, and higher SD values.

The correlation coefficients revealed no statistically significant differences between the water and sediment variables, except for a weak positive coefficient for water and sediment TP (Fig. 7). This suggested that the $\mathrm{P}$ present in the water was stored in the sediment, in agreement with the higher sediment $\mathrm{P}$ values for the Jaguari and Jacareí reservoirs (Fig. 5).

The $\mathrm{N}$ and $\mathrm{P}$ concentrations in the water and sediment were lower than reported for other reservoirs, especially eutrophic ones (Table 5). In water, the N/P molar ratio (19 to 380 ) was higher than in the sediment

Table 4. Linear correlations among Secchi disk depth (SD), organic fraction of suspended solids (SSO), inorganic fraction of suspended solids (SSI), and chlorophyll-a concentration (Chla) for two sampling periods

\begin{tabular}{|c|c|c|c|}
\hline Sampling period & Variables & Linear correlation & Probability \\
\hline \multirow[t]{5}{*}{ First: May/June 2013} & SSI / Chla & -0.2400 & $p>0.3$ \\
\hline & SSI / SD & -0.5403 & $p<0.02$ \\
\hline & SsO / Chla & 0.9701 & $p<0.001$ \\
\hline & SSO / SD & -0.2459 & $p>0.3$ \\
\hline & Chla / SD & -0.3326 & $p>0.1$ \\
\hline \multirow[t]{5}{*}{ Second: November/December 2013} & SSI / Chla & 0.8513 & $p<0.001$ \\
\hline & $\mathrm{SSI} / \mathrm{SD}$ & -0.6995 & $p<0.001$ \\
\hline & SsO / Chla & 0.9385 & $p<0.001$ \\
\hline & $\mathrm{SSO} / \mathrm{SD}$ & -0.7471 & $p<0.001$ \\
\hline & Chla / SD & -0.7689 & $p<0.001$ \\
\hline
\end{tabular}



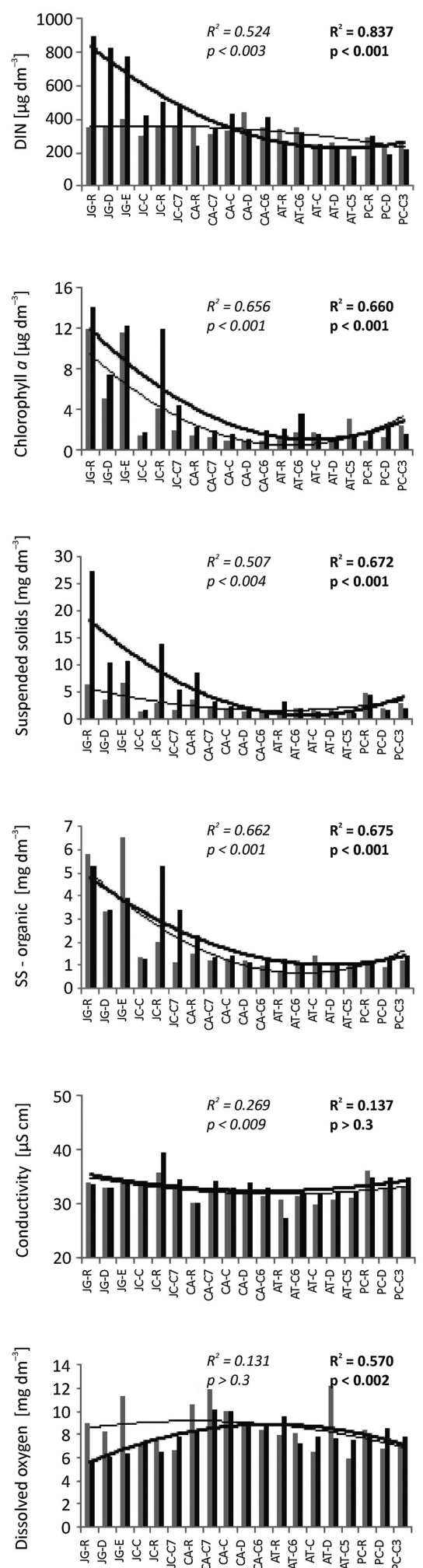
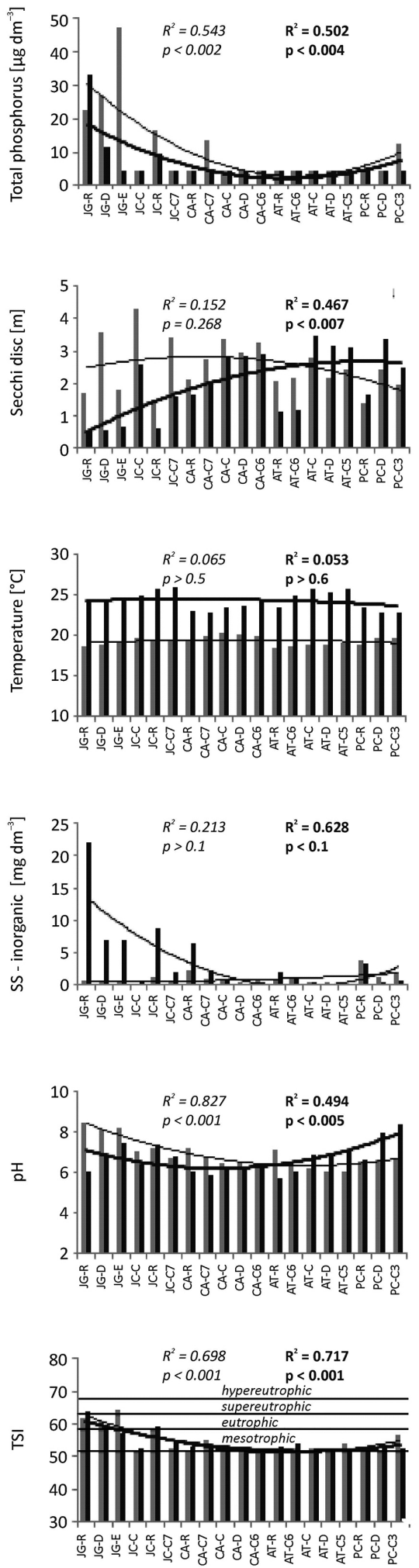

Fig. 3. Variables analyzed in the water column at different sampling sites in the Jaguari (JG), Jacareí (JC), Cachoeira (CA), Atibainha (AT), and Paiva Castro (PC) reservoirs. Gray bars, thin lines, and italics represent May/June 2013 sampling; Black bars, thick lines, and bold type represent November/December 2013 sampling

Explanations: DIN - nitrite + nitrate + ammonium; SS - suspended solids; TSI - trophic state index; R - river; C - center; D - dam; C7, C6, and C5 - connecting channels between the reservoirs; C3 - water outlet channel to Santa Ines pumping station. Trend lines are second order polynomials 

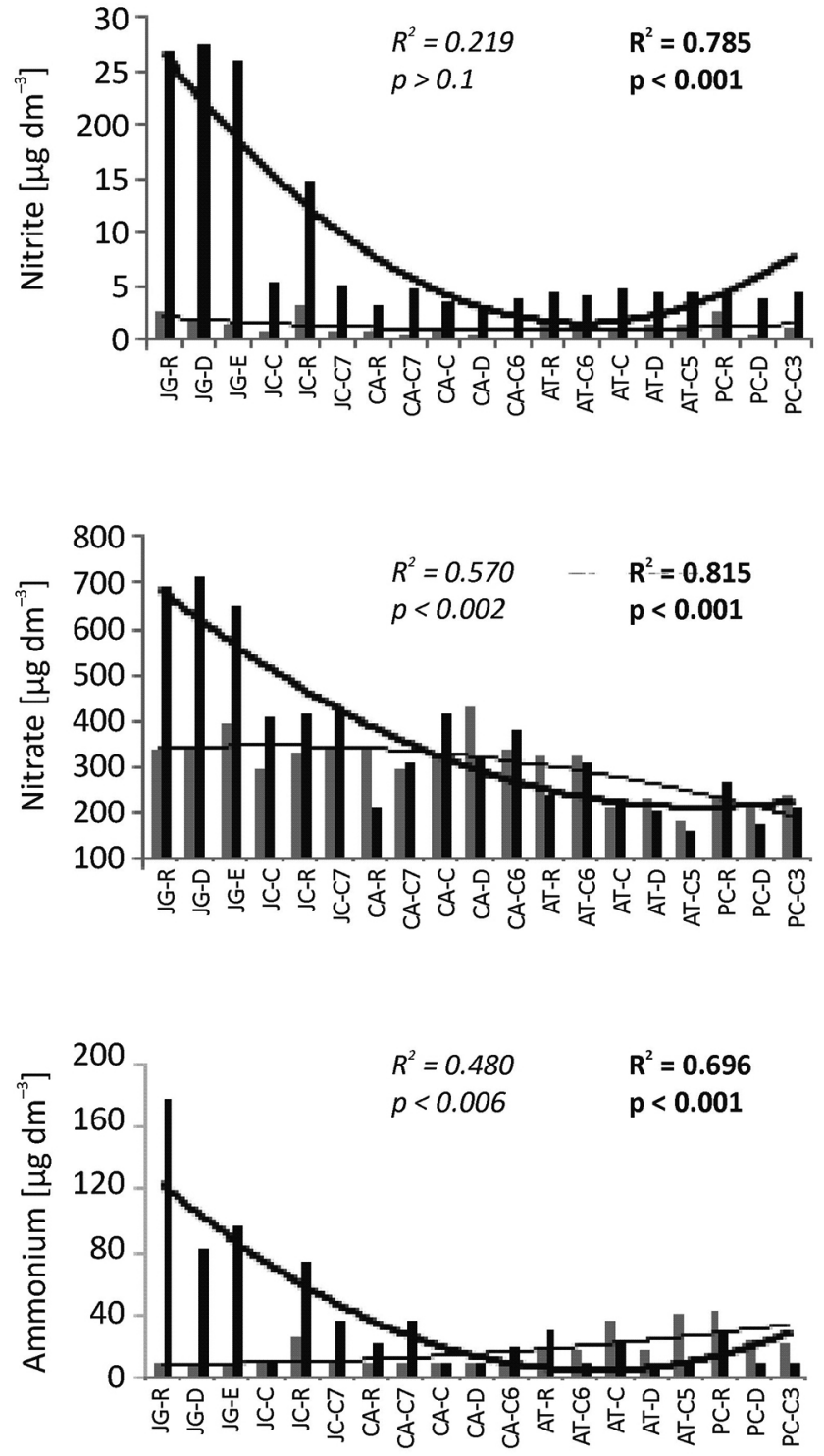

Fig. 4. Nitrite, nitrate, and ammonium concentrations in the water columns at different sampling sites in the Jaguari (JG), Jacareí (JC), Cachoeira (CA), Atibainha (AT), and Paiva Castro (PC) reservoirs. Gray bars, thin lines, and italics represent May/June 2013 sampling; Black bars, thick lines, and bold type represent November/December 2013 sampling

Explanations: R - river; C - center; D - dam; C7, C6, and C5 - connecting channels between reservoirs; C3 - water outlet channel to Santa Ines pumping station. Trend lines are second order polynomials

(7 to 29) and was much higher than the Redfield rate (16:1) (Fig. 8 and Table 3). Since the $\mathrm{N}$ fraction was calculated as DIN in this study, the values would be even higher if calculated using TN. These ratios suggest that $\mathrm{P}$ is a mainly limiting factor of phytoplankton growth in the studied reservoirs. Already, the lower levels of TKN/TP in the sediment could be ascribed to two processes. The first was the accumulation of $\mathrm{P}$ in the sediment, in agreement with the regressions between
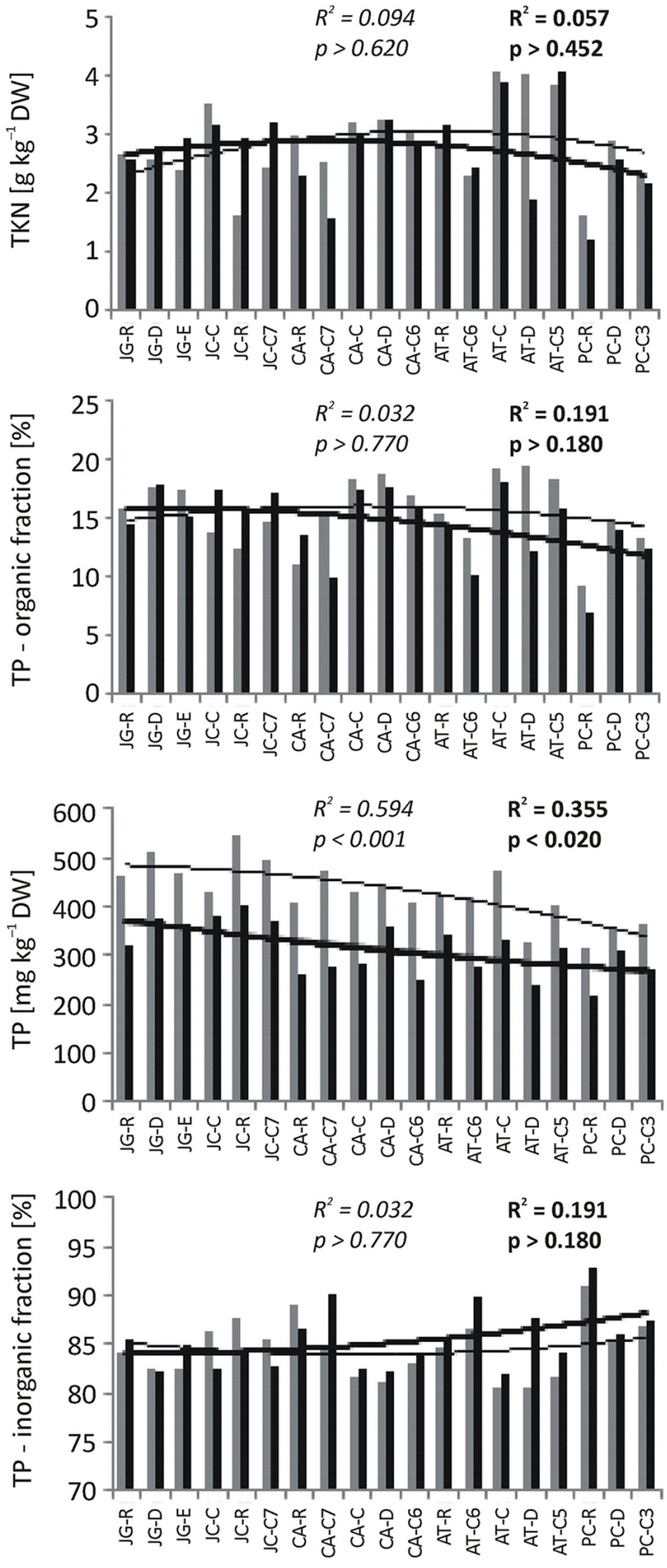

Fig. 5. Variables analyzed in the sediment from different sampling sites in the Jaguari (JG), Jacarei (JC), Cachoeira (CA), Atibainha (AT), and Paiva Castro (PC) reservoirs. Gray bars, thin lines, and italics represent May/June 2013 sampling; Black bars, thick lines, and bold type represent November/December 2013 sampling Explanations: TKN - total Kjeldahl nitrogen; TP - total phosphorus; R river; C - center; D - dam; C7, C6, and C5 - connecting channels between the reservoirs; C3: water outlet channel to Santa Ines pumping station. Trend lines are second order polynomials 
Table 5. Total nitrogen and phosphorus concentrations (ranges and mean values) reported in waters and sediments

\begin{tabular}{|c|c|c|c|c|c|c|}
\hline \multirow{3}{*}{ Reservoir/system } & \multirow{3}{*}{ Anthropogenic impact } & \multicolumn{2}{|c|}{ Water } & \multicolumn{2}{|c|}{ Sediment } & \multirow{3}{*}{ References } \\
\hline & & TN & TP & TN & TP & \\
\hline & & {$\left[\mu \mathrm{g} \mathrm{N} \mathrm{dm}{ }^{-3}\right]$} & {$\left[\mu \mathrm{g} \mathrm{P} \mathrm{dm}{ }^{-3}\right]$} & {$\left[\mathrm{g} \mathrm{N} \mathrm{kg}{ }^{-1} \mathrm{DW}\right]$} & $\begin{array}{l}{\left[\mathrm{mg} \mathrm{P} \mathrm{kg}^{-}\right.} \\
\left.{ }^{1} \mathrm{DW}\right]\end{array}$ & \\
\hline $\begin{array}{l}\text { Armando Ribeiro } \\
\text { Gonçalves (Itajá) (Brazil) }\end{array}$ & $\begin{array}{l}\text { Eutrophic to } \\
\text { hypereutrophic }\end{array}$ & $\begin{array}{c}2800-4800 \\
(3700)\end{array}$ & $\begin{array}{c}40-200 \\
(95)\end{array}$ & NA & NA & $\begin{array}{c}\text { Eskinazi-Sant'Anna et } \\
\text { al. (2007) }\end{array}$ \\
\hline Gargalheiras (Brazil) & $\begin{array}{l}\text { Eutrophic to } \\
\text { supereutrophic }\end{array}$ & $\begin{array}{c}1500-15800 \\
(8000)\end{array}$ & $\begin{array}{l}50-600 \\
(200)\end{array}$ & NA & NA & \\
\hline $\begin{array}{l}\text { Itans, Parelhas, } \\
\text { Passagem das Traíras, } \\
\text { Sabugi (Brazil) }\end{array}$ & Mesotrophic to eutrophic & $\begin{array}{l}1200-14000 \\
(7112.5)\end{array}$ & $\begin{array}{c}10-270 \\
(120)\end{array}$ & NA & NA & \\
\hline Salto Grande (Brazil) & $\begin{array}{l}\text { Eutrophic and } \\
\text { supereutrophic, with } \\
\text { hypertrophic points }\end{array}$ & NA & NA & $0.09-2.8^{*}$ & $47.58-1208$ & Dornfeld et al. (2004) \\
\hline Salto Grande (Brazil) & $\begin{array}{l}\text { Eutrophic and } \\
\text { supereutrophic, with } \\
\text { hypertrophic points }\end{array}$ & $40-33700^{*}$ & $30-890$ & NA & NA & Espíndola et al. (2004) \\
\hline $\begin{array}{l}\text { Different reservoirs in } \\
\text { São Paulo State (Brazil) }\end{array}$ & $\begin{array}{l}11.5 \% \text { oligo-, } 48 \% \text { meso- } \\
, 30 \% \text { eu-, } 8 \% \text { supereu-, } \\
\text { and } 2.5 \% \text { hypereutrophic }\end{array}$ & $\begin{array}{l}71-57150 \\
(2180)\end{array}$ & $\begin{array}{c}4-1400 \\
(75)\end{array}$ & NA & NA & Lamparelli (2004) \\
\hline $\begin{array}{l}\text { Eight reservoirs along } \\
\text { the Paranapanema R. } \\
\text { (Brazil) }\end{array}$ & $\begin{array}{l}\text { Mesotrophic with } \\
\text { eutrophic points }\end{array}$ & $\begin{array}{c}337-513 \\
(411.1)\end{array}$ & $\begin{array}{l}8-119 \\
(30.8)\end{array}$ & $0-10.9$ & $0-1960$ & $\begin{array}{c}\text { Nogueira (2000) } \\
\text { Jorcin and Nogueira } \\
(2005 \mathrm{~b}) \\
\end{array}$ \\
\hline $\begin{array}{l}\text { Vargem das Flores } \\
\text { (Brazil) }\end{array}$ & $\begin{array}{l}34.8 \% \text { of the stations } \\
\text { impacted by human } \\
\text { activity }\end{array}$ & (90) & $(26.6)$ & NA & NA & Molozzi et al. (2011) \\
\hline Ibiritê (Brazil) & $\begin{array}{l}\text { Eutrophic }-46.6 \% \text { of } \\
\text { the stations impacted by } \\
\text { human activities }\end{array}$ & $(260)$ & $(114.2)$ & NA & NA & \\
\hline Lake Taihu, China & Eutrophic & $\begin{array}{c}1240-9480 \\
(3540)\end{array}$ & $\begin{array}{c}60-320 \\
(130)\end{array}$ & NA & NA & Xu et al. (2010) \\
\hline $\begin{array}{l}\text { Six reservoirs along the } \\
\text { Tietê R., São Paulo State } \\
\text { (Brazil) }\end{array}$ & Oligotrophic to eutrophic & $50-1770^{*}$ & $20-230$ & $1.45-44.38$ & $3030-63050$ & $\begin{array}{l}\text { Rodgher et al. (2005) } \\
\text { Smith et al. (2014) }\end{array}$ \\
\hline $\begin{array}{l}\text { Klusov Reservoir } \\
\text { (Slovakia) }\end{array}$ & $\begin{array}{l}\text { Land use in the } \\
\text { catchment area: mixed } \\
\text { type }\end{array}$ & NA & NA & $1.1-2.6$ & $0.4-1.1$ & $\begin{array}{c}\text { Junakova and Balintova } \\
\text { (2012) }\end{array}$ \\
\hline $\begin{array}{l}\text { Changtan Reservoir } \\
\text { (China) }\end{array}$ & Eutrophic & NA & NA & $\sim 2.0-4.0$ & $300-900$ & Ding and Jiang (2012) \\
\hline Jaguari/Jacarei (Brazil) & $\begin{array}{l}\text { Mesotrophic to } \\
\text { hypereutrophic }\end{array}$ & $170-370^{* * *}$ & $<18-79.3$ & NA & $360-405$ & Hackbart et al. (2015) \\
\hline Jaguari & Eutrophic & $\begin{array}{c}348-900 \\
(611)\end{array}$ & $\begin{array}{l}<9-47 \\
(24.4) \\
\end{array}$ & $\begin{array}{c}2.4-3^{* *} \\
(2.7)\end{array}$ & $\begin{array}{c}320-510 \\
(416.8)\end{array}$ & This study \\
\hline Jacareí & Mesotrophic & $\begin{array}{c}306-507 \\
(434.5)\end{array}$ & $\begin{array}{c}<9-17 \\
(7.3)\end{array}$ & $\begin{array}{c}1.6-3.5^{\star *} \\
(2.8)\end{array}$ & $\begin{array}{c}370-548 \\
(438)\end{array}$ & \\
\hline $\begin{array}{l}\text { Cachoeira, Atibainha, } \\
\text { Paiva Castro }\end{array}$ & Oligotrophic/mesotrophic & $\begin{array}{c}178-439 \\
(338.5)\end{array}$ & $\begin{array}{c}<9-14 \\
(5.2) \\
\end{array}$ & $\begin{array}{c}1.2-4.1^{* *} \\
(2.73)\end{array}$ & $\begin{array}{l}217-473 \\
(339.63) \\
\end{array}$ & \\
\hline
\end{tabular}

${ }^{*}$ Total Organic Nitrogen (TON); ${ }^{* *}$ Total Kjeldahl Nitrogen (TKN); ${ }^{* *}$ Dissolved inorganic nitrogen (DIN), the sum of nitrite, nitrate, and ammonium concentrations; NA - not available

TP in water and sediment, and the second process was denitrification, which can remove substantial amounts of deposited nitrogen from the sediment (Golterman 2004; David et al. 2006).

The cluster analyses (Fig. 9) showed a grouping with the Jaguari reservoir separated from the other reservoirs. In the PCA results (Fig. 10), component 1 (which explained $39.67 \%$ of the variability) separated the reservoirs according to the nutrient concentrations in the water and sediment. The Cachoeira and Atibainha reservoirs showed the highest concentrations of organic matter in the water (41.0 to $77.5 \%)$ and sediment (11.8 to $19.38 \%$ ), while the Paiva Castro showed a higher inorganic matter fraction (water: 20.6 to $41.6 \%$; sediment: 9.21 to $17.78 \%)$. Component $2(29.48 \%$ of the variability) separated the reservoirs into two groups. One group was composed of the Jaguari and Jacareí reservoirs, with high levels of TSI, DIN, SS, and TP in the sedi- 

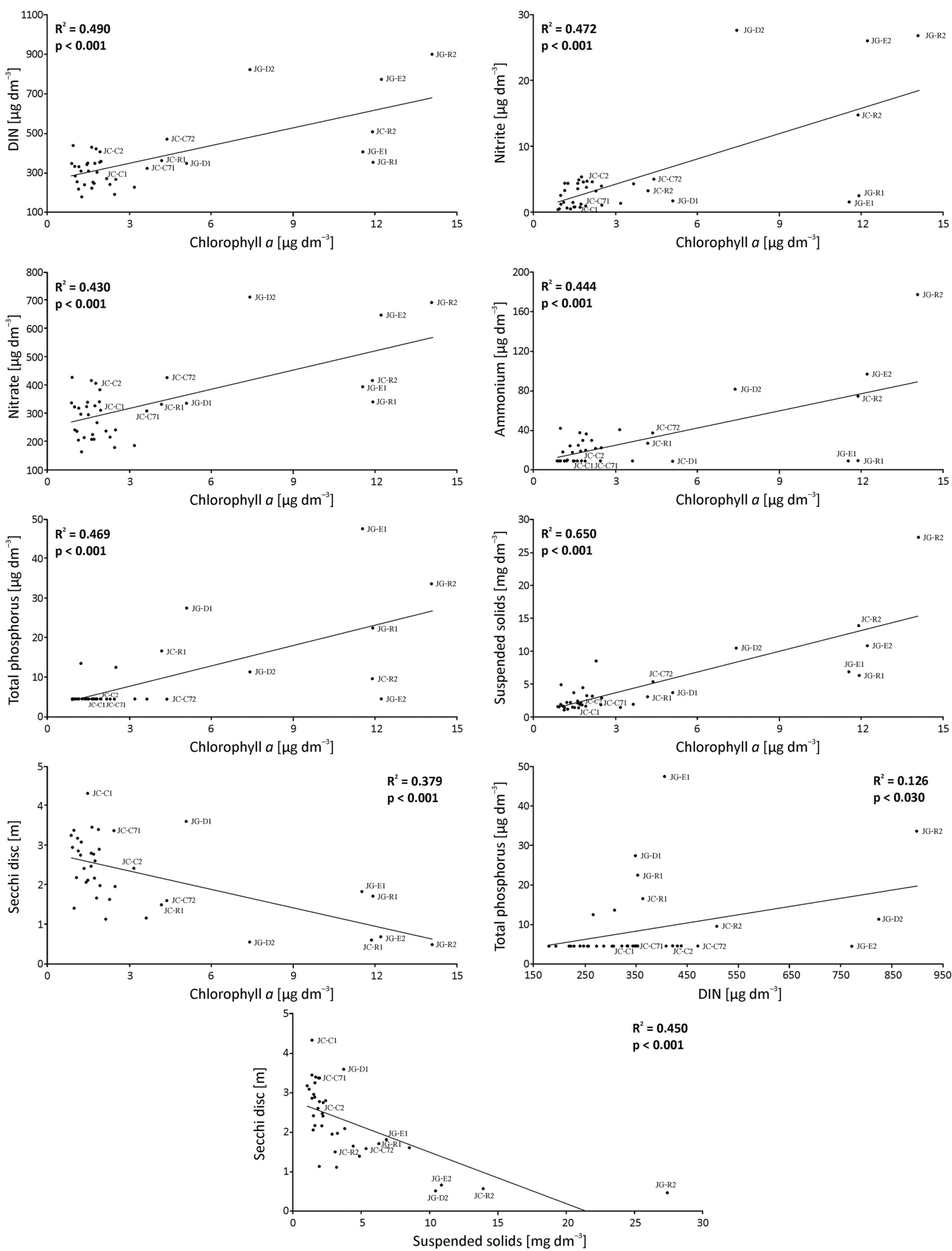

Fig. 6. Relationships between the water column variables (only the data for the Jaguari (JG) and Jacarei (JC) reservoirs are presented in order to avoid excessive overlapping of text in the graphs). Numbers after the symbols indicate the May/June 2013 (1) and November/December 2013 (2) sampling periods

Explanation: DIN - dissolved inorganic nitrogen (nitrite + nitrate + ammonium concentrations) 

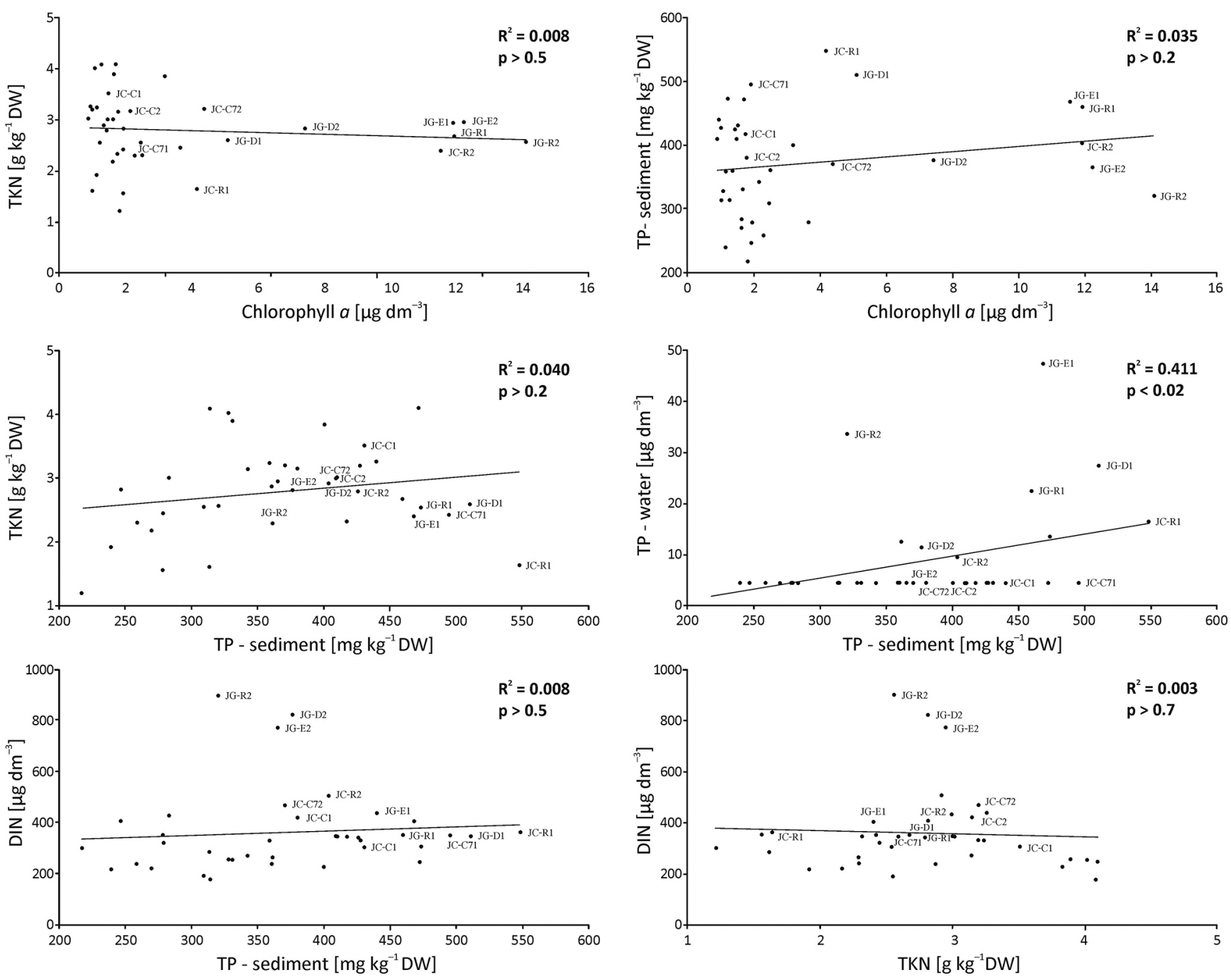

Fig. 7. Linear regressions between the water and sediment variables. Only the data for the Jaguari (JG) and Jacarei (JC) reservoirs are presented in order to avoid excessive overlapping of text in the graphs. Numbers after the symbols indicate the May/June 2013 (1) and November/December 2013 (2) sampling periods

Explanations: TNK - total Kjeldahl nitrogen; TP - total phosphorus; DIN - dissolved inorganic nitrogen

ment, in contrast to the other reservoirs, so the second component appeared to be related to eutrophication. Both components evidenced that the Jaguari and Jacareí were different from the other reservoirs.

Pompêo, Casas-Ruiz et al. (2015) also observed spatial heterogeneity in Spanish reservoirs, between river zone, central and the dam, as expected. It was found that reservoirs with the greatest anthropogenic activities in the watersheds presented greater anthropogenic contributions of metals, as well as higher trophic levels. In the present study, some of the individual reservoirs showed a gradient from the upper portion to the dam, as observed by Mariani and Pompêo (2008) and Pompêo et al. (2013) for metals in the sediments of the Rio Grande and Guarapiranga reservoirs (Brazil). Similar patterns for concentrations of $\mathrm{N}$ and $\mathrm{P}$ in sediment were observed in the five cascade reservoirs in the River
Lozoya (central Spain), with spatial heterogeneity both among and within reservoirs (Lopez et al. 2009).

Concerning the water column, Pedrazzi et al. (2013), Cardoso-Silva et al. (2014), and Pompêo, Kawamura et al. (2015) observed horizontal spatial heterogeneity, with a river to dam gradient. In the specific case of the CS, work by Hackbart et al. (2015), considering the water and sediment, suggested the existence of horizontal spatial heterogeneity and the presence of compartments, especially in the Jaguari and Jacareí reservoirs.

In cascade systems, the capacity of one reservoir to influence another located downstream depends on its characteristics (Barbosa et al. 1999; Straškraba and Tundisi 2013). Downstream reservoirs are influenced to a greater degree by deep and stratified reservoirs than by shallow and unstratified reservoirs. The intensity of this influence also depends on the order of the 
A - water
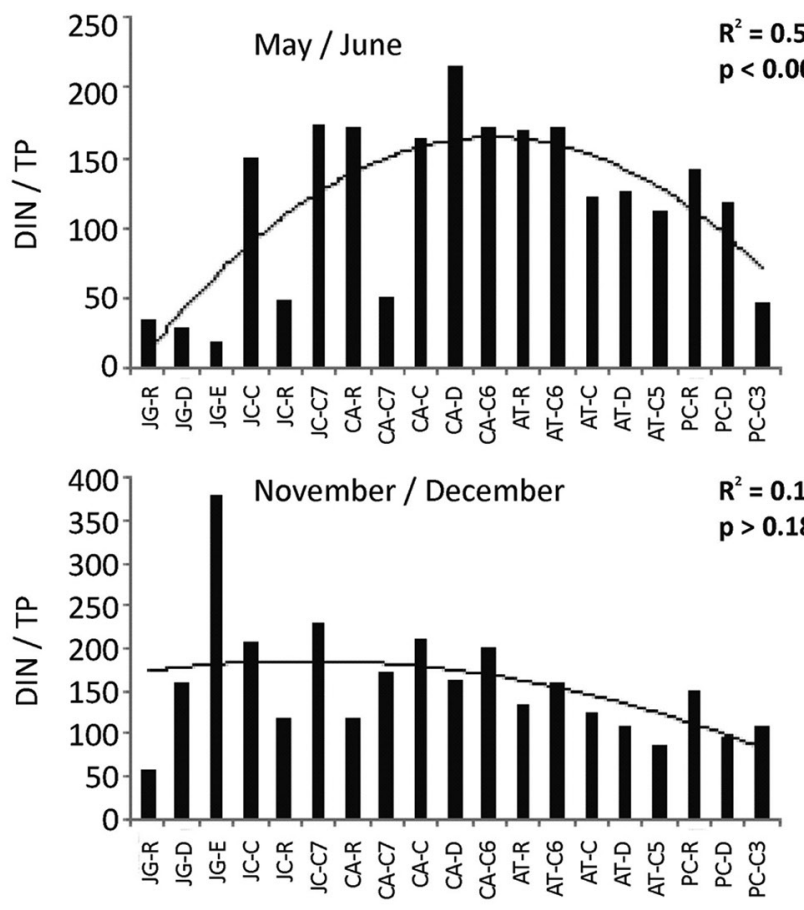

B - sediment
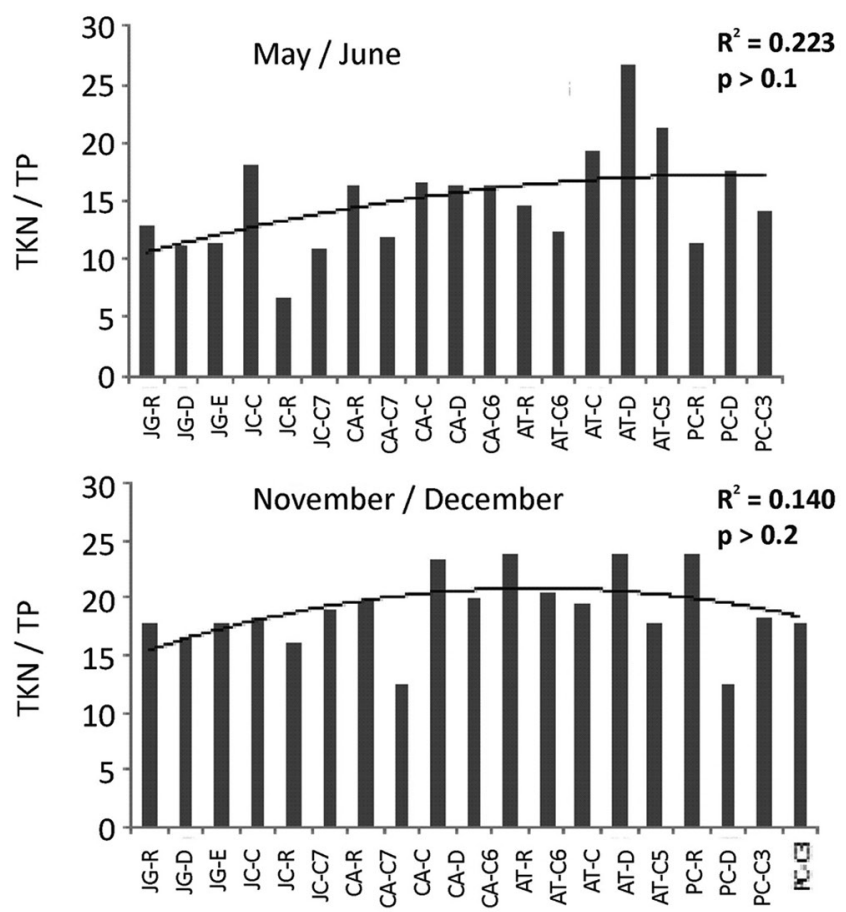

Fig. 8. Molar ratios between $\mathrm{N}$ and $\mathrm{P}$ in (a) water and (b) sediment collected in different seasons in the Jaguari (JG), Jacareí (JC), Cachoeira (CA), Atibainha (AT), and Paiva Castro (PC) reservoirs

Explanations: TKN - total Kjeldahl nitrogen; TP - total phosphorus; DIN - dissolved inorganic nitrogen; $\mathrm{R}$ - river; C - center; D - dam; C7, C6, and C5 - connecting channels between the reservoirs; C3 - water outlet channel to Santa Ines pumping station. Trend lines are second order polynomials

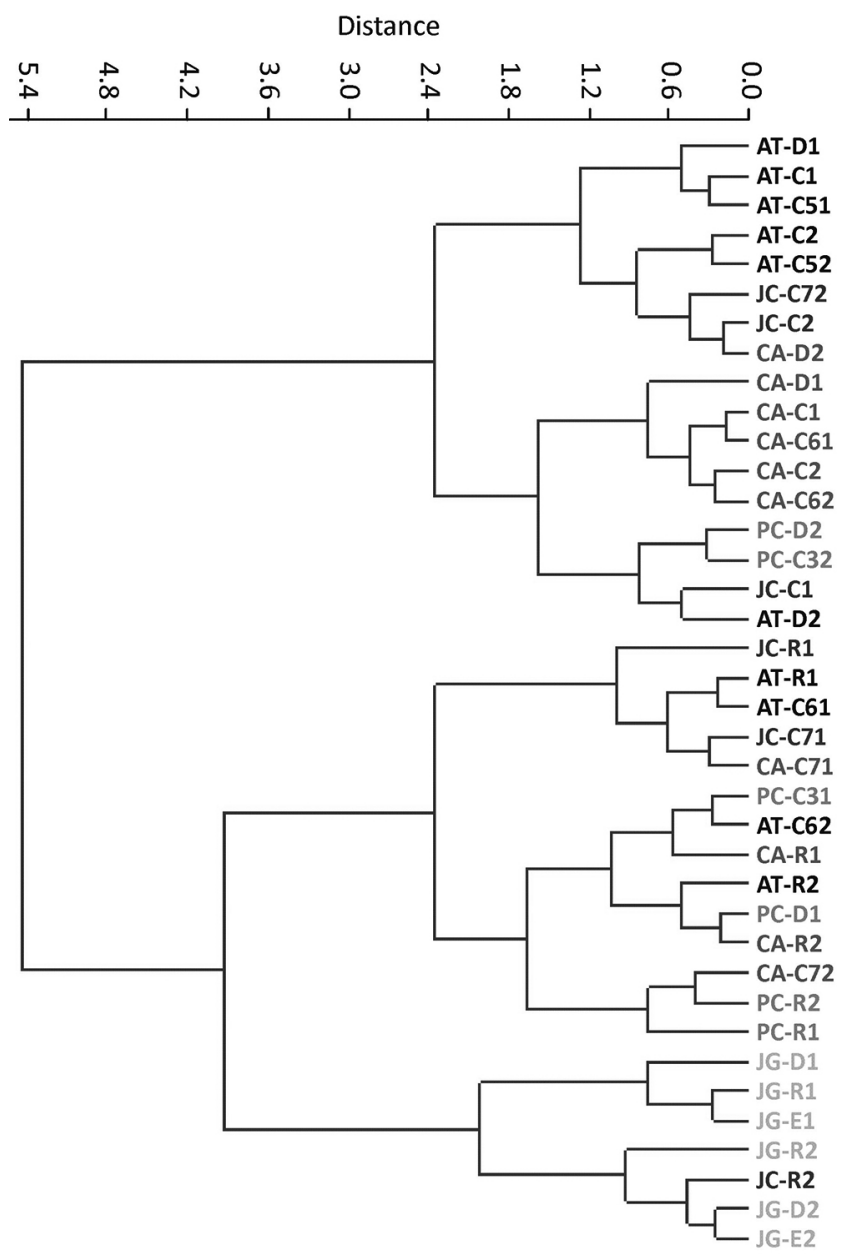

Fig. 9. Cluster analysis of water and sediment variables of the Cantareira System reservoirs Jaguari (JG), Jacareí (JC), Cachoeira (CA), Atibainha (AT), and Paiva Castro (PC), using Euclidean distances and Ward's method

Explanations: R - river; C - center; D - dam; C7, C6, and C5 - connecting channels between the reservoirs; C3 - water outlet channel to Santa Ines pumping station. Numbers after the symbols indicate the May/June 2013 (1) and November/December 2013 (2) sampling periods

river that connects the water bodies, the trophic level of the upstream reservoir, and the distance between them. Reservoirs located in higher order rivers have longer residence times and greater effects on the downstream rivers. The distance between reservoirs is also relevant, because within a distance of hundreds of kilometers from the upstream reservoir, the river returns to the natural state and the effects of that system are no longer active. The most significant effects occur closer to the reservoirs. In the case of the CS, the distances between the reservoirs are short and the water flows through closed channels and tunnels. Consequently, the water passes directly between the reservoirs without any significant alterations of its physical and chemical characteristics or by biofilm activity (Stevenson 1996; Sabater et al. 2002; Ensign and Doyle 2006). This feature 
increases the influence of the upstream reservoirs on the downstream ones.

Some of the effects observed by Straškraba (1990) in cascade reservoirs could be relevant in the case of the $\mathrm{CS}$ reservoirs. For example, $\mathrm{P}$ concentrations strongly decreased in the downstream reservoirs of the CS, probably due to greater sedimentation upstream (Conceição et al. 2015), with sedimentation and fixation by phytoplankton (Straškraba et al. 1993) being the most likely explanation for the lower concentrations observed in the downstream reservoirs.

Nevertheless, the patterns expected for cascade reservoirs were not always clearly observed (Jorcin and Nogueira 2005a,b; Nogueira et al. 2007). Those authors observed that the sampling points located in the intermediate portion of the River Parapanema (Brazil) were more eutrophic, which was explained by high exportation rates and increased concentrations of sediment and nutrients in the reservoir, due to intense agricultural activities in the surroundings of the intermediate portion. Therefore, the contributions of the watershed of a certain reservoir could enhance the levels of nutri- ents and, therefore, the trophic state, interfering with the theoretical patterns expected in cascade reservoirs.

In another study concerning spatial variation in a cascade system of six reservoirs located along the Tietê River (São Paulo State, Brazil), Rodgher et al. (2005) and Smith et al. (2014) observed that TN and TP showed the same patterns of variation in water and sediment, as suggested by the CRCC (Barbosa et al. 1999). The patterns were similar to those observed in the present study. Elsewhere, a trend of decreasing nutrients and increasing transparency, due to the accumulation of solids in the upstream reservoirs, was observed for five cascade reservoirs along the São Francisco River in northeast Brazil (Lima and Severi 2014). Nevertheless, as observed by Jorcin and Nogueira $(2005 \mathrm{a}, \mathrm{b})$ and Nogueira et al. (2007), the intermediate reservoirs of the São Francisco River were subject to modifications associated directly with the presence of tributaries and surrounding cities.

According to the Brazilian water quality standards, based on the uses of water bodies (CONAMA 2005), the present results indicate that the water of the CS res-

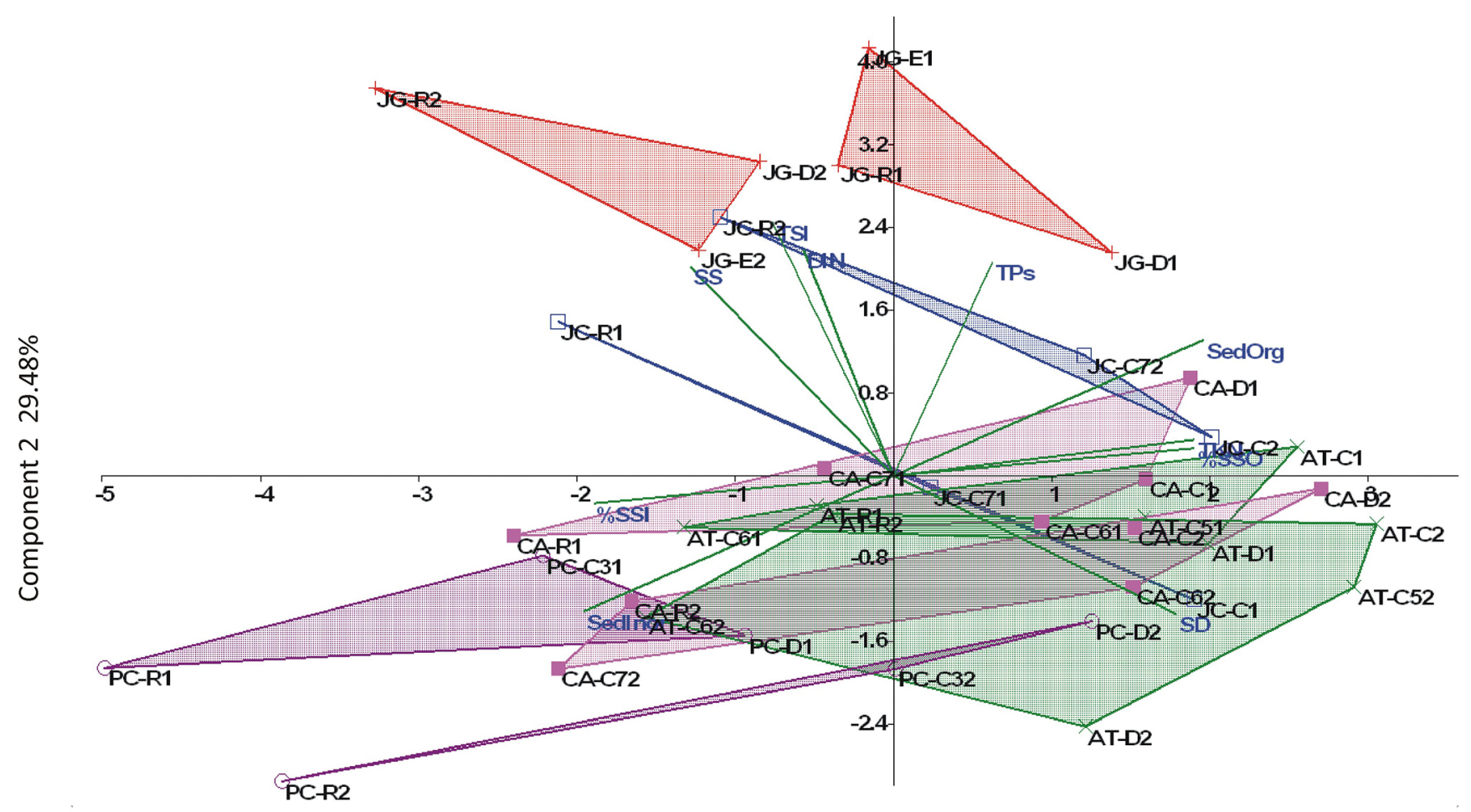

Component 1 39.67\%

Fig. 10. Principal component analysis of water and sediment variables of the Cantareira System reservoirs Jaguari (JG), Jacareí (JC), Cachoeira (CA), Atibainha (AT), and Paiva Castro (PC). Numbers after the symbols indicate the May/June 2013 (1) and November/December 2013 (2) sampling periods

Explanations: R - river; C center; D - dam; C7, C6, and C5 - connecting channels between the reservoirs; C3 - water outlet channel to Santa Ines pumping station. TKN - total Kjeldahl nitrogen; TPw - total phosphorus in water; DIN - dissolved inorganic nitrogen; TSI - trophic state index; TPs - total phosphorus in sediment; SedOrg - organic fraction of sediment; SedInor - inorganic fraction of sediment; SD - Secchi disk; SS - suspended solids; \%SSO - organic fraction of suspended solids; \%SSI - inorganic fraction of suspended solids 
ervoirs should be classified as no better than Class 2 . This is water destined for human consumption, after traditional treatment; for protection of aquatic communities; for recreation with primary contact; for irrigation of vegetables, fruit trees, plants and parks, gardens, and sports and leisure areas, with which the public may have direct contact; and for aquaculture and fishing. The data are worrying, because the Paiva Castro, the last reservoir of the CS, which provides water to the treatment station, has to achieve Class 1 quality, according to the CONAMA resolution No 357 (CONAMA 2005). This classification imposes greater restrictions in terms of water quality and protection of the surrounding areas. Hence, progressive goals should be established aiming to improve the quality of the CS reservoirs, focusing on achieving high water quality and sustainability in the long term. Specifically, for the Jaguari and Jacareí reservoirs, Hackbart et al. (2015) indicate that TSI values from 54 to 69 represent trophic levels from meso to hypereutrophic, which are incompatible with the criteria for Class 1 water quality (CONAMA 2005).

The patterns of the concentrations of DIN, TP, nitrite, nitrate, ammonium, chlorophyll- $a$, SD and suspended solids determined in this research corroborate the CRCC (Barbosa et al. 1999), with the upstream reservoirs being more eutrophic and the downstream ones being more oligotrophic, suggesting low contributions from the watershed areas of the intermediate reservoirs. The data also suggest that the low phytoplankton biomass observed in the reservoirs is regulated by the low nutrient availability, with the upstream reservoirs functioning as nutrient accumulators and the sediment as the main compartment for storage of $\mathrm{P}$ and $\mathrm{N}$. These results also demonstrate the urgent need for restoration measures in the upstream reservoirs (especially the Jaguari and Jacareí), as previously suggested for the reservoirs of the Tietê River basin (Barbosa et al. 1999). Performing the first interventions in the upstream basins would optimize efforts and financial resources, because undertaking actions upstream of multi-system reservoirs in cascade leads to positive impacts in the downstream chain of reservoirs.

\section{Acknowledgements}

The authors are grateful to FAPESP for financial support (procs. 2012/11890-4, 2013/03494-4, and 2014/22581-8); to the Bioscience Institute for logistical support; to Geison Castro, Jose Flaviano Oliveira, and Maurício Perini for assistance during the work; to Carlos Roberto Dardis (Division Manager, Sabesp) for the facilities provided during fieldwork at the Cachoeira Reservoir; and to Marina Confiança (Bragança Paulista, SP), for all the support provided.

\section{References}

Almeida G.A., Weber R.R., 2005, Fármacos na represa Billings (Pharmaceuticals in the Billings Reservoir), Rev. Saúde Amb. 6(2): 7-13 (in Portuguese).

[ANA-DAEE] Agência Nacional de Águas. Departamento de Águas e Energia Elétrica (National Water Agency. Department of Water and Electrical Energy), 2013, Dados de referência acerca da outorga do Sistema Cantareira (Reference data for the Cantareira System). Retrieved from: www.agua.org.br/editor/file/cantareira/dados.pdf. (Accessed on 29 September 2014).

Andersen J.M., 1976, An ignition method for determination of total phosphorus in lake sediments, Water Res. 10: 329-331.

[APHA] American Public Health Association, 2005, Standard Methods for the Examination of Water and Wastewater, APHA-AWWA-WEF, Washington.

Azevedo L.B., van Zelm R., Leuven R.S.E.W., Hendriks A.J., Huijbregts M.A.J., 2015, Combined ecological risks of nitrogen and phosphorus in European freshwaters, Environ. Pollut. 200: 85-92.

Barbosa A.M.C., Solano M..LM., Umbuzeiro G.A., 2015, Pesticides in drinking water - the Brazilian monitoring program, Front. Public Health 3: 246.

Barbosa F.A.R., Padisák J., Espíndola E.L.G., Borics G., Rocha O., 1999, The cascading reservoir continuum concept (CRCC) and its application to the river Tietê basin, São Paulo State, Brazil, [in:] Tundisi J.G., Straškraba M. (eds), Theoretical reservoir ecology and its applications, Backhuys, Leiden: 425-437.

Becker V., Caputo L., Ordóñez J., Marcé R., Armengol J., Crossetti L.O., Huszar V.L.M., 2010, Driving factors of the phytoplankton functional groups in a deep Mediterranean reservoir, Water Res. 44(11): 3345-3354.

Bergamasco A.M.D.D., Sékula C., Daniel M.H.B., Queiroz F.B., Cabral A.R., 2011, Contaminantes químicos em águas destinadas ao consumo humano no Brasil (Drinking water chemical contaminants in Brazil), Cad. Saúde Colet. 19(4): 479-86 (in Portuguese, English summary).

Braga B.P.F., Porto M.F.A., Silva R.T., 2006, Water management in metropolitan São Paulo, Int. J. Water. Resour. D. 22(2) 337-352.

Caleffi S., 2000, Impacto do uso de sulfato de cobre sobre o zooplâncton na represa Guarapiranga (Impact of the use of copper sulphate on zooplankton in the Guarapiranga Reservoir), [in:] Espíndola E.L.G., Paschoal C.M.R.B,, Rocha O., Bohrer M.B.C., Oliveira Neto A.L. (eds), Ecotoxicologia: Perspectivas para o Século XXI (Ecotoxicology: Perspectives for the 21st Century), RiMa Editora, São Carlos: 3-14 (in Portuguese).

Cardoso-Silva S., Nishimura P.Y., Padial P.R., Mariani C.F., Moschini-Carlos V., Pompêo M., 2014, Compartimentalização e qualidade da água: o caso da Represa Billings (Compartmentalization and water quality: Billings reser- 
voir case), Bioikos 28(1): 31-43 (in Portuguese, English summary).

Carlson R.E., 1977, A trophic state index for lakes, Limnol. Oceanogr. 22(2): 361-369.

Carvalho G.B.B., Thomas P.T., 2007, Repartição das vazões transpostas da bacia hidrográfica do rio Piracicaba para a bacia hidrográfica do Alto Tietê pelo Sistema Cantareira para fins de cobrança pelo uso de recursos hídricos (Distribution of the transposed flows from the Piracicaba river basin to the Alto Tietê basin by the Cantareira System for the purpose of charging for the use of water resources), XVII Simpósio Brasileiro de Recursos Hídricos, ABRH, São Paulo: 11 pp (in Portuguese, English summary).

[CETESB] Companhia de Tecnologia de Saneamento Ambiental, 2008, Relatório de qualidade das águas interiores no Estado de São Paulo 2007 (Inland water quality report for the State of São Paulo 2007), Governo do Estado de São Paulo - Secretaria de Estado do Meio Ambiente, São Paulo, 537 pp (in Portuguese).

[CETESB] Companhia de Tecnologia de Saneamento Ambiental, 2013, Qualidade das águas superficiass no Estado de São Paulo 2012 (Surface water quality in the State of São Paulo 2012), Governo do Estado de São Paulo - Secretaria de Estado do Meio Ambiente, São Paulo 370 pp (in Portuguese).

Cole G.A., 1979, Textbook of Limnology, Mosby Company, Saint Louis, $281 \mathrm{pp}$.

[CONAMA] Conselho Nacional do Meio Ambiente (National Council for the Environment), 2005, Resolução No 357, de 17 de março de 2005, Dispõe sobre a classificação dos corpos de água e diretrizes ambientais para o seu enquadramento, bem como estabelece as condições e padrões de lançamento de efluentes, e dá outras providências (Resolution No. 357 of March 17, 2005, provides for the classification of water bodies and environmental guidelines for their classification, as well as establishes the conditions and standards for effluent discharge, and provides other measures), Diário Oficial da União (DOU) 53: 58-63. Retrieved from http://www.siam.mg.gov.br/sla/download. pdf?idNorma=2747 [Accessed 6 June 2016] (in Portuguese).

Conceição F.T., Sardinha D.S., Godoy L.H., Fernandes A.M., Pedrazzi F.J.M., 2015, Influência sazonal no transporte específico de metais totais e dissolvidos nas águas fluviais da bacia do Alto Sorocaba (SP) (Seasonal influence on the specific transport of total and dissolved metals in the fluvial waters of the Alto Sorocaba basin), Geochim. Bras. 29(1): 23-34 (in Portuguese).

David M.B., Wall L.G., Royer T.V., Tank J.L., 2006, Denitrification and the nitrogen budget of a reservoir in an agricultural landscape, Ecol. Appl. 16(6): 2177-2190.

[DDE] District Department of the Environment, 2012, 2011 \& 2012 DC MS4 Annual Report. Municipal Separate Storm Sewer System, NPDES Permit No. DC0000221, Government of the District of Columbia, Washington, 93 pp. Retrieved from https://doee.dc.gov/sites/default/ files/dc/sites/ddoe/ publication/attachments/2012\%20 Annual\%20Report\%202-26-13\%20-\%20Amended.pdf [Accessed 12 July 2016].

Ding X., Jiang C., 2012, Pollutions characteristics of nutrients in sediment at Changang Reservoir, Procedia Eng. 28: $178-181$.

Dornfeld C.B., Leite M.A., Espíndola E.L.G., 2004, Caracterização física e química do sedimento do reservatório de Salto Grande, Americana, SP (Physical and chemical characterization of sediment from Salto Grande reservoir, Americana, SP), [in:] Espíndola E.L.G., Leite M.A., Dornfeld C.B. (eds), Reservatório de Salto Grande (Americana, SP): Caracterização, impactos e propostas de manejo (Salto Grande Reservoir (Americana, SP): Characterization, impacts and management proposals), RiMa Editora, São Carlos: 91-105 (in Portuguese).

Ducrot R., Kruitwagen M., Wagemans F., van Essen P., Jacobi P., 2005, Land and water management in the Metropolitan Region of Sao Paulo: Presentation of the geographic and institutional context, PROCAM-USP, São Paulo, 18 pp.

Ensign S.H., Doyle M.W., 2006, Nutrient spiraling in streams and river networks, J. Geophys. Res. 111(G04009): 1-13.

Eskinazi-Sant'Anna E.M., Menezes R., Costa I.S., Panosso R.F., Araújo M.F., Attayde J.L., 2007, Composição da comunidade zooplanctônica em reservatórios eutróficos do semi-árido do Rio Grande do Norte (Zooplankton composition in eutrophic reservoirs of the semi-arid region of Rio Grande do Norte state), Oecol. Bras. 11(3): 410-421 (in Portuguese, English summary).

Espíndola E.L.G., Rocha O., Rietzler A.C., 2004, Caracterização limnológica do reservatório de Salto Grande (Americana, SP): Uma análise espacial e temporal (Limnological characterization of the Salto Grande reservoir (Americana, SP): a spatial and temporal analysis), [in:] Espíndola E.L.G., Leite M.A., Dornfeld C.B. (eds), Reservatório de Salto Grande (Americana, SP): Caracterização, impactos e propostas de manejo (Salto Grande Reservoir (Americana, SP): Characterization, impacts and management proposals), RiMa Editora, São Carlos: 37-54 (in Portuguese).

Golterman H.L., 2004, The chemistry of phosphate and nitrogen compounds in sediments, Kluwer, Dordrecht, 251 pp.

Gomes L.C., 2004, Outorga de recursos hídricos no Estado de São Paulo (Granting of water resources in the State of São Paulo) [PowerPoint presentation], Departamento de Águas e Energia Elétrica (DAEE), São Paulo, 33 pp. Retrieved from http://www.comitepcj.sp.gov.br/download/ DAEE_Leila_29-01-04.pps [Accessed 9 May 2015].

Hackbart V.C.S., Marques A.R.P., Kida B.M.S., Tolussi C.E., Negri D.D.B., Martins I.A, Fontana I., Collucci M.P., Brandimarti A.L., Moschini-Carlos V., Cardoso-Silva S., Merinho P.A, Freire R.H.F., Pompêo M., 2015, Avaliação expedita da heterogeneidade espacial horizontal intra e inter reservatórios do Sistema Cantareira: repre- 
sas Jaguari e Jacarei, São Paulo (Expedited evaluation of horizontal spatial heterogeneity within and between reservoirs of the Cantareira System: Jaguari and Jacarei reservoirs, São Paulo), [in:] Pompêo M., Moschini-Carlos V., Nishimura P.Y., Cardoso-Silva S., López-Doval J.C. (eds), Ecologia de reservatórios e interfaces (Ecology of reservoirs and interfaces), Instituto de Biociências USP, São Paulo: 96-108 (in Portuguese).

Hammer Ø., Harper D.A.T., Ryan P.D., 2001, Past: Paleontological Statistics Software Package for Education and Data Analysis, Palaeontol. Electron. 4(1) art. \#4: 1-9.

Huerta B., Marti E., Gros M., López P., Pompêo M., Armengol J., Barceló D., Balcázar J.L., Rodríguez-Mozaz S., Marcé R., 2013, Exploring the links between antibiotic occurrence, antibiotic resistance, and bacterial communities in water supply reservoirs, Sci. Total Environ. 456-457: 161-170.

[INAG IP] Instituto da Água (Water Institute), 2009, Manual para a avaliação da qualidade biológica da água. Protocolo de amostragem e análise para o Fitoplâncton (Manual for the evaluation of the biological quality of water. Sampling and analysis protocol for phytoplankton), Ministério do Ambiente, do Ordenamento do Território e do Desenvolvimento Regional. Instituto da Água I.P., Lisboa, $67 \mathrm{pp}$ (in Portuguese).

Jones O.A., Lester J.N., Voulvoulis N., 2005, Pharmaceuticals: a threat to drinking water?, Trends Biotechnol. 23(4): 163-167.

Jorcin A., Nogueira M.G., 2005a, Phosphate distribution in the sediments along a cascade of reservoirs (Paranapanema River, SE, Brazil), [in:] Serrano L., Golterman H.L. (eds.), Phosphates in Sediments, Proc. of the $4^{\text {th }}$ International Symposium, Backhuys, Leiden: 77-86.

Jorcin A., Nogueira M.G., 2005b, Temporal and spatial patterns based on sediment and sediment-water interface characteristics along a cascade of reservoirs (Paranapanema River, south-east Brazil), Lake Reserv. Manage. 10(1): 1-12.

Junakova N., Balintova M., 2012, Assessment of nutrient concentration in reservoir bottom sediments, Procedia Eng. 42: 165-170.

Kimmel B.L., Lind O.T., Paulson L.J., 1990, Reservoir primary production, [in:] Thorton K.W., Kimmel B.L., Payne F.E. (eds.), Reservoir limnology: ecological perspectives, Wiley, New York: 133-194.

Koroleff M., 1976, Determination of nutrients, [in:] Grasshoff K. (ed.), Methods of sea water analysis, Verlag Chemie, Weinhein: 117-181.

Lamparelli M.C., 2004, Graus de trofia em corpos d'água de estado de São Paulo: Avaliação dos métodos de monitoramento (Thropic status in São Paulo state water bodies: evaluation of monitoring methodologies) [ $\mathrm{PhD}$ thesis], Instituto de Biociências, Universidade de São Paulo, São Paulo, 238 pp (in Portuguese, English summary).

Lehner B., Liermann C.R., Revenga C., Vörösmarty C., Fekete B., Crouzet P., Döll P., Endejan M., Frenken K., Magome
J., Nilsson C., Robertson J.C., Rödel R., Sindorf N., Wisser D., 2011, High-resolution mapping of the world's reservoirs and dams for sustainable river-flow management, Front. Ecol. Environ. 9(9): 494-502.

Lewis G.M., Chen A.S.C., Wang L., 2007, Arsenic removal from drinking water by point of use reverse osmosis (POU RO): U.S. EPA Demonstration Project at Sunset Ranch Development in Homedale, ID: Final Performance Evaluation Report, Report No: EPA 600/R-07/082, U.S. Environmental Protection Agency, Washington, $58 \mathrm{pp}$.

Lima A.E., Severi W., 2014, Estado trófico na cascata de reservatórios de um rio no semiárido brasileiro (Trophic state of reservoirs in the cascade of a river in the Brazilian semiarid), Rev. Bras. Ciênc. Agrár. 9(1): 124-133 (in Portuguese, English summary).

Liu H., Pan D., Chen P., 2016, A two-year field study and evaluation of water quality and trophic state of a large shallow drinking water reservoir in Shanghai: China, Desalin. Water Treat. 57(29): 13829-13829.

López-Doval J.C., Barata C., Díez S., 2015, El uso de organismos como indicadores de la contaminación y evaluación del riesgo sobre el ecosistema acuático en el embalse de Flix: Catalunya, NE de España (The use of organisms as indicators of pollution and risk assessment on the aquatic ecosystem in the Flix reservoir: Catalunya, NE, Spain), [in:] Pompêo M., Moschini-Carlos V., Nishimura P.Y., Cardoso-Silva S., López-Doval J.C. (eds), Ecologia de reservatórios e interfaces (Ecology of reservoirs), Instituto de Biociências USP, São Paulo: 1-32 (in Portuguese).

Lopez P., Marcé R., Ordoñez J., Urrutia I., Armengol J., 2009, Sedimentary phosphorus in a cascade of five reservoirs (Lozoya River, Central Spain), Lake Reserv. Manage. 25(1): 39-48.

Lorenzen C.J., 1967, Determination of chlorophyll and pheo-pigments: spectrophotometric equations, Limnol. Oceanogr. 12(2): 343-346.

Mackereth F.J.H., Heron J., Talling J.F., 1978, Water analysis: some revised methods for limnologists, Freshwater Biological Assn., Ambleside, $121 \mathrm{pp}$.

Margalef R., Planas D., Armengol J., Vidal A., Prat N., Guiset A., Toja J., Estrada M., 1976, Limnología de los embalses españoles (Limnology of the Spanish reservoirs), MOP Publicación No 123, D.G. Obras Hidráulicas MOP, Madrid, 462 pp (in Spanish).

Mariani C.M., Pompêo M., 2008, Potentially bioavailability metals in sediment from a tropical polymictic environment - Rio Grande Reservoir: Brazil, J. Soils Sediments 8(5): 284-288.

Meguro M., 2000, Métodos em Ecologia (Methods in ecology), USP, São Paulo, 117 pp (in Portuguese).

Molozzi J., França J.S., Araujo T.L.A., Viana T.H., Hughes R.M., Callisto M., 2011, Diversidade de habitats físicos e sua relação com macroinvertebrados bentônicos em reservatórios urbanos em Minas Gerais (Diversity of physical habitat and its relationship with benthic macroinvertebrates in urban reservoirs in Minas Gerais), Iheringia, 
Sér. Zool. 101(3): 191-199 (in Portuguese, English summary).

Moschini-Carlos V., Bortoli S., Pinto E., Nishimura P.Y., Freitas L.G., Pompêo M., Dörr F., 2009, Cyanobacteria and cyanotoxin in the Billings Reservoir (São Paulo, SP, Brazil), Limnetica 28(2): 273-282.

Moschini-Carlos V., Freitas L.G., Pompêo M., 2010, Limnological evaluation of water in the Rio Grande and Taquacetuba branches of the Billings Complex (São Paulo, Brazil) and management implications, Amb-Agua 5(3): 47-59.

Navarro E., Bacardit M., Caputo L., Palau T., Armengol J., 2006, Limnological characterization and flow patterns of a three-coupled reservoir system and their influence on Dreissena polymorpha populations and settlement during the stratification period, Lake Reserv. Manage. 22(4): 293-302.

Newman M.M., Dixon P.M., Looney B.B., Pinder J.E., 1989, Estimating mean and variance for environmental samples with below detection limit observations, Water Resour. Bull. 25(4): 905-916.

Nishimura P.Y., Meirinho P.A., Moschini-Carlos V., Pompêo M., 2014, Does the plankton community follow the horizontal water quality heterogeneity in a tropical urban reservoir (Guarapiranga reservoir, São Paulo, Brazil)?, Limnetica 33(2): 263-280.

Nogueira M.G., 2000, Phytoplankton composition, dominance and abundance as indicators of environmental compartmentalization in Jurumirim Reservoir (Paranapanema River), São Paulo, Brazil, Hydrobiologia 431(2-3): 115-128.

Nogueira M.G., Jorcin A., Vianna N.C., Britto Y.C.T., 2007, Reservatórios em cascata e os efeitos na limnologia e organização das comunidades bióticas (fitoplâncton, zooplâncton e zoobentos) - um estudo de caso no rio Paranapanema (SP/PR) (Cascade reservoirs and the effects on limnology and organization of biotic communities (phytoplankton, zooplankton and zoobenthos) - a case study on the River Paranapanema (SP/PR)), [in:] Nogueira M.G., Henry R., Jorcin A. (eds.), Ecologia de reservatórios: impactos potenciais, ações e manejo de sistemas em cascata (Reservoir ecology: potential impacts, actions and management of cascade systems), RiMa Editora, São Carlos: 83-125 (in Portuguese).

Pedrazzi F.J.M., Conceição F.T., Sardinha D.S., MoschiniCarlos V., Pompêo M., 2013, Spatial and temporal quality of water in the Itupararanga Reservoir, Alto Sorocaba Basin (SP), Brazil, J. Water Resour. Prot. (JWARP) 5(1): 64-71.

Pereira C.A.A.O., 2013, Plano Diretor de aproveitamento de recursos hídricos para a Macrometrópole Paulista, no Estado de São Paulo. Relatório Final - Volume I (Master Plan for the use of water resources for the Macrometropole Paulista, in the State of São Paulo. Final Report - Volume I), Departamento de Águas e Energia Elétrica (DAEE), 195 pp (in Portuguese).
Pompêo M., Casas-Ruiz J.P, Moschini-Carlos V., Marcé R., Nishimura P.Y., Armengol J., López P., 2015, Chemical elements in superficial sediments of five reservoirs in the Catalonia and Aragon region (Spain): Is there an anthropogenic contribution?, [in:] Pompêo M., Moschini-Carlos V., Nishimura P.Y., Cardoso-Silva S., López-Doval J.C. (eds), Ecologia de reservatórios e interfaces (Ecology of reservoirs and interfaces), Instituto de Biociências USP, São Paulo: 251-277.

Pompêo M., Kawamura P., Moschini-Carlos V., CardosoSilva S., Lobo F.L., Meirinho P.A., Bitencourt M.D., Meirelles S.T., 2015, Heterogeneidade espacial horizontal da qualidade da água no reservatório Rio Grande, Complexo Billings, São Paulo, Brasil (Horizontal spatial heterogeneity of water quality in the Rio Grande Reservoir, Billings Complex), [in:] Pompêo M., Moschini-Carlos V., Nishimura P.Y., Cardoso-Silva S., López-Doval J.C. (eds), Ecologia de reservatórios e interfaces (Ecology of reservoirs and interfaces), Instituto de Biociências USP, São Paulo: 82-95 (in Portuguese).

Pompêo M., Moschini-Carlos V., 2012, O abastecimento de água e o esgotamento sanitário: propostas para minimizar os problemas no Brasil (Water supply and sanitary sewage: proposals to minimize problems in Brazil), [in]: Rosa A.H., Fraceto L.F., Moschini-Carlos V. (eds.), Meio ambiente e sustentabilidade (Environment and sustainability), Bookman Companhia Editora, Porto Alegre: 41-61 (in Portuguese).

Pompêo M., Padial P.R., Mariani C.F., Cardoso-Silva S., Moschini-Carlos V., Silva D.C.V.R., Brazil T.C.P., Brandimarte A.L., 2013, Biodisponibilidade de metais no sedimento de um reservatório tropical urbano (reservatório Guarapiranga, São Paulo, Brasil): há toxicidade potencial e heterogeneidade espacial? (Bioavailability of metals in the sediment of an urban tropical reservoir (Guarapiranga reservoir, São Paulo, Brazil): is there potential toxicity and spatial heterogeneity?), Geochim. Bras. 27(2): 104119 (in Portuguese, English summary).

Qin B.Q., Gao G., Zhu G.W., Zhang Y.L., Song Y.Z., Tang X.M., Xu H., Deng J.M., 2013, Lake eutrophication and its ecosystem response, Chin. Sci. Bull. 58(9): 961-970.

Rodgher S., Espíndola E.L.G., Rocha O., Fracácio R., Pereira R.H.G., Rodrigues M.H.S., 2005, Limnological and ecotoxicological studies in the cascades of reservoirs in the Tietê River (São Paulo, Brazil), Braz. J. Biol. 65(4): 697710.

Sabater S., Guasch H., Romaní A., Muñoz I., 2002, The effect of biological factors on the efficiency of river biofilms in improving water quality, Hydrobiologia 469(1-3): 149156.

Santos S., Oliveira L.C., Santos A., Rocha J.C., Rosa H.A., 2012, Poluição aquática (Water pollution), [in:] Rosa A.H., Fraceto L.F., Moschini-Carlos V. (eds.), Meio ambiente e sustentabilidade (Environment and sustainability), Bookman Companhia Editora, Porto Alegre: 11-40. 
[SEADE] Fundação Sistema Estadual de Análise de Dados (Statewise System for Data Analysis Foundation), 2015, Portal de Estatísticas do Estado de São Paulo., Retrieved from http://produtos.seade.gov.br/produtos/perfil_regional/ (Accessed 23 November 2015).

Smith W.S., Espíndola E.L.G., Rocha O., 2014, Environmental gradient in reservoirs of the medium and low Tietê River: limnological diferences through the habitat sequence, Acta Limnol. Bras. 26(1): 73-88.

Sodré F.F., Locatelli M.A.F., Jardim W.F., 2010, Occurrence of emerging contaminants in Brazilian drinking waters: a sewage-to-tap issue, Water Air Soil Poll. 206(1-4): 57-67.

Stevenson R.J., 1996, An introduction to algal ecology in freshwater benthic habitats, [in:] Stevenson R.J., Bothwell M.L., Lowe R.L. (eds.), Algal ecology: freshwater benthic ecosystems, Academic Press, San Diego: 3-30.

Straškraba M., 1990, Limnological particularities of multiple reservoir series, Arch. Hydrobiol. Beih. Ergebn. Limnol. 33: 677-678.

Straškraba M., Tundisi J.G., Duncan A., 1993, State-of-theart of reservoir limnology and water quality management, [in:] Straškraba M., Tundisi J.G., Duncan A. (eds.), Comparative limnology and water management, Kluwer, Dordrecht: 213-288.

Straškraba M., Tundisi J.G., 2013, Aspectos técnicos da construção de reservatórios (Technical aspects of reservoir construction), Oficina de Textos, São Carlos, 300 pp (in Portuguese).

Tundisi J.G., Matsumura-Tundisi T., 2008, Limnologia (Limnology), Oficina de Textos, São Paulo, 632 pp (in Portuguese).

Tundisi J.G., Matsumura-Tundisi T., 2010, Ciência, tecnologia, inovação e recursos hídricos: Oportunidades para o futuro (Science, technology, innovation and water resources: Opportunities for the future), [in:] Bicudo C.E.M., Tundisi J.G., Scheuenstuhl M.C.B. (eds), Águas do Brasil: Análises estratégicas (Waters of Brazil: Strategic analysis), Academia Brasileira de Ciencias - Instituto de Botânica, São Paulo: 179-197.

Tundisi J.G., Rocha O., Matsumura-Tundisi T., Braga B., 1998, Reservoir management in South America, Int. J. Water Resour. D. 14(2): 141-155.

[UNEP-IETC] United Nations Environment Programme - International Environment Tecnology Centre, 2001, Planejamento e gerenciamento de lagos e represas: uma abordagem integrada ao problema da eutrofização (Planning and management of lakes and reservoirs: An integrated approach to eutrophication), RiMa Editora, São Carlos, 385 pp (in Portuguese).

Valderrama J.C., 1981, The simultaneous analysis of total nitrogen and phosphorus in natural waters, Mar. Chem. 10(2): 109-122.

Vallentyne J.R., 1978, Introducción a la Limnología (Introduction to Limnology), Ed. Omega, Barcelona, 180 pp (in Spanish).

Vidović M.M., Rodić M.N., Vidović M.U., Trajković I.S., Jovanić S.Z., 2015, Assessment of the trophic status by monitoring of reservoir's water quality, J. Water Resour. Prot. (JWARP) 7(1): 1-13.

Wetzel R.G., Likens G.E., 1991, Limnological analyses, Springer-Verlag, New York: 391 pp.

Whately M., Cunha P., 2007, Cantareira 2006: Um olhar sobre o maior manancial de água da Região Metropolitana de São Paulo. Resultados do diagnóstico socioambiental participativo do Sistema Cantareira, Instituto Socioambiental (ISA), São Paulo, 67 pp (in Portuguese). Retrieved from http://www.socioambiental.org/banco_imagens/ pdfs/10289.pdf. [Accessed 10 October 2015].

Xu H., Paerl H.W., Qin B., Zhu G., Gao G., 2010, Nitrogen and phosphorus inputs control phytoplankton growth in eutrophic Lake Taihu, China, Limnol. Oceanogr. 55(1): 420-443. 